\title{
LEGAL PROTECTION FOR CHILDREN AS A VICTIM OF SEXUAL VIOLENCE: ANALYSIS OF THE DECISION OF THE COURT OF SEXUAL VIOLENCE ON CHILDREN UNDER THE AGE OF 2006-2015
}

\author{
Siswantari Pratiwi* \\ * Doctoral of Law Program \\ Universitas Krisnadwipayana Jakarta \\ PO BOX 7774/JAT CM Jakarta 13077, Indonesia \\ Email: sistariwangi@ymail.com \\ Indonesia
}

\section{ABSTRACT}

Children are often considered to be weak, innocent, and easily deceived, when children are free from parental supervision, they are vulnerable to being victims of sexual violence by immoral people who want to satisfy their sexual desires without thinking about the suffering they have to go through. Various rules have been arranged to protect children, but in reality, sexual violence against children continues to occur, this has led to public unrest, especially parents. For this reason, this study was conducted to find out how much the child victims of sexual violence have the highest priority to get protection in law enforcement practices so far. Data analysis techniques used a normative juridical research approach, and the results of interviews with informants as well as an analysis of court decisions on cases of sexual violence against children, in DKI Jakarta and Bekasi.

The research proves that protecting children as victims of sexual violence is not limited to applying criminal sanctions or fines on the perpetrators, but must be accompanied by other protections such as assistance, granting their rights to obtain compensation, restitution, and assistance as mandated by law. Ideally, protection for the victim is given at every examination process until the criminal conviction. This is done to realize fair and beneficial law enforcement for children. The protection of children as victims of sexual violence has not been in favor of the interests of victims, the rights of children as victims such as the provision of compensation, restitution, and assistance to victims have not been implemented properly. This is because there is still a lack of understanding of law enforcement officials and the public about the importance of protecting victims. Therefore, as a protection effort that can be done, it is necessary to build a criminal justice system that is more in favor of the interests of children as victims, as well as improvements to the rules so that it is more in the interests of the victims. As soon as possible the regulation of the law is issued as a guideline for executing sentences so as not to cause controversy in the community. Through the application of sanctions that are just and impartial to the interests of the perpetrators, then justice for the victims will be realized.

\section{Keywords: legal protection, child protection, victims of sexual violence, case court decisions INTRODUCTION}

Protection of children as victims of violence should be able to function to protect the rights and interests of children and be useful in restoring the physical and psychological condition of children due to the violence they experience (Law No. 31:2014). This is because the essence of protection for children as victims of violence is very important in the development of children in the future so that not only the punishment of the perpetrators but also the fulfillment of children's rights as victims that must be considered as expressly stipulated in the law.

Likewise, legal protection for children who are victims of sexual violence must immediately be treated seriously and optimally, to be able to do their normal activities. Children victims of violence generally experience trauma due to the violence they experienced, therefore fulfilling the rights of children as victims, such as the right to the availability of justice mechanisms and obtaining compensation, the right of victims to protection from harassment/intimidation from perpetrators, the right to medical assistance, psychosocial and psychological rehabilitation assistance, as well as other rights stipulated in applicable laws.

Legal protection for children as victims of sexual violence is a national and international issue that needs serious attention. This can be proven by the establishment of the Declaration of Basic, Principal of Justice for Victims of Crime and Abuse of Power by the United Nations, which is the result of the seven United Nation Congresses on The Prevention of Crime and The Treatment of Offenders, which took place in Milan, Italy, in September 1985. 
The Declaration of Basic Principles of Justice for Victims of Crime and Abuse of Power contains the following conditions: a). victims are entitled to immediate compensation for the losses they suffered; b). they must be informed of their rights to receive compensation; c). the perpetrators or third parties must provide fair restitution for the victims, their families, and their responsibilities. Such compensation must include the return of ownership or payment of suffering or loss suffered, reimbursement of costs incurred as a result of victimization, and the provision of services and restoration of rights; d). When compensation is not fully obtained from actors or other sources, the state must try to provide financial compensation; e). Victims must receive the necessary material, medical, psychological and social support and assistance.

The United Nations (UN) with UN General Assembly Resolution No. 56/138 of 2001 assigned the UN Secretary-General to hold a special study on violence against children in the world. This study is a global initiative that recognizes the occurrence of violence against children in the world community. This proves a case of violence against children has become a serious concern from all corners of the world.

In the view of Yulia (2010), there are 4 (four) important things that must be considered about the UN Declaration, namely: a). access to justice and fair treatment; b). Restitution by the perpetrators of criminal acts to victims, their families or other people whose lives are formulated in the form of criminal sanctions in applicable legislation; c). if the convict is unable, the state is expected to pay financial compensation to victims, their families or those who are victims of the victims; d). material, medical, psychological and social assistance to victims, through the state, volunteers and the community (assistance). Immediate reimbursement for the loss caused by the victim, especially as a result of sexual violence, will greatly assist the victim in recovering her disrupted health condition.

The fulfillment of children's rights as victims is a right that must not be ignored. The perpetrators of sexual violence or parties who have harmed the victim should assist the victim, either in the form of restitution for the needs of the initial examination and treatment caused by the victim's suffering, as well as reimbursement of further medical and/or psychological care costs of the victim. If the victim dies, restitution is given to the victim's family who is the victim's heir. The law is quite firm in regulating the rights of victims, all that remains is how to implement it in judicial practice. Aside from being a form of protection for victims provided by the state, if the perpetrator is unable to provide full compensation which is his responsibility to the victim or his family, compensation can be requested from the state through the Witness and Victim Protection Agency (LPSK).

In Indonesia, sexual violence against children received attention from the community because of its development, cases of violence against children from year to year showed a quite alarming increase. The Attorney General's official data, in 2006, there were 600 cases of violence against children who have permanent legal force consisting of fornication cases $41.3 \%$, rape $40.5 \%$, mistreatment $7.2 \%$, sexual abuse $5.3 \%$, acts criminal trafficking in persons 3\%, and murder 2.7\% (Regulation of the Minister of State for the Empowerment of Women and Child Protection of the Republic of Indonesia Number 02 of 2011). This data shows the number of cases of violence against children that lead to sexual shows at $91 \%$. If grouped in the age group, of the 600 cases $57.3 \%$ were 13-18 years old, $35.4 \%$ were $6-12$ years old, and $7.3 \%$ were less than 5 years old. This data shows, there is no longer a safe age limit for children free from the terrible threat of child predators.

The Indonesian Child Protection Commission records cases of child complaints based on child protection clusters from 2011 to 2017 as follows. 1. Child victims of online sexual crime 418 cases; 2. Children as victims of sexual violence (rape, molestation, sodomy, pedophilia) 2171 cases, 3. Children as victims of online prostitution 498 cases, and 4. Children as victims of commercial sexual exploitation of children (CSEC) 400 cases (Indonesian Child Protection Commission for Information and Complaints Data 2017).

LPSK data records, almost every week there are at least 4 (four) cases of sexual violence that are decided (handled), where the numbers from 2016 to 2019 continue to increase significantly based on the number of requests that enter LPSK (DetikNews. July 24, 2019). This number is certainly not the real number of sexual violence, because there are likely to be many cases of sexual violence that do not reach the LPSK. In the LPSK notes, there was an increase in cases of sexual violence against children that occurred from 2016 to 2018. In 2016 sexual violence against children amounted to 25 cases, increasing to 81 cases in 2017, and the peak in 2018 to 206 cases. While the number of children victims of sexual violence in 2016 was 35 victims, in 2017 it increased to 70 people, and 2018 
amounted to 149. Until June 2019, requests for cases of sexual violence against children had reached 78 cases (Matthew, 2019). While the perpetrators of sexual violence against children are dominated by closest people, that are 80.23 percent, the remaining 19.77 percent is committed by unknown people.

This data proves cases of sexual violence by making children victims from time to time continues to occur, even there is a tendency to continue to increase, so it cannot be ignored to get serious attention given the child's future is threatened. This data is only based on complaints, meaning that there may be cases of sexual violence that are not reported or processed legally. Based on these data, it is clear that some children are in an insecure position, meaning that the danger of sexual violence can threaten children at any time.

Legislation that can be used as a legal umbrella for children who are victims of sexual violence, including the Declaration of Basic Principles of Justice for Victims of Crime and Abuse of Power, Law Number 23 of 2002 concerning Child Protection which has been amended by the Law Number 35 of 2014 and amended by Law Number 17 of 2016 concerning Child Protection, Act Number 23 of 2004 concerning the Elimination of Domestic Violence (Article 10); Law Number 13 of 2006 concerning Protection of Witnesses and Victims which has been amended by Law Number 31 of 2014, along with the implementing regulations.

The provision of guarantees for the protection of children's rights as victims of sexual violence has an important role in the criminal justice process so that witnesses and victims are provided free from fear and threat to reveal a criminal act. Guaranteed legal protection provided for in this law will provide benefits for victims, witnesses, and the public as well as for law enforcement to uncover criminal acts.

Child protection is a joint responsibility between the state, the Government, the family community and also parents as regulated in Article 20 of Law Number 23 Year 2002 concerning Child Protection, which determines: "The state, government, community, family, and parents are obliged to and responsible for the implementation of child protection ". Ensuring child protection is the responsibility of every member of the community following their abilities with various businesses in certain situations and conditions.

The principles of child protection contained in Article 2 of Law Number 23 of 2002 concerning Child Protection, which reads "The implementation of child protection based on Pancasila and based on the 1945 Constitution of the Republic of Indonesia and the basic principles of the Convention on the Rights of the Child which includes: a. non-discrimination; b. the best interests of the child; c. the right to life, survival, and development; and d. respect for children's opinions. The principles of child protection are following the convention on the right of the child.

The principle of best interests for children, as referred to in the explanation of Article 2 of Law Number 23 of 2002 concerning child protection, is intended in all actions concerning children carried out by the government, community, legislative and judicial bodies, the best interests of the child must be the main consideration. This means that everything that aims for the best interests of the child is a top priority.

Law Number 35 the Year 2014, which is a change from Law Number 23 the Year 2002, regulates several "special protections" aimed at children, namely a. children who are exploited economically and/or sexually (Article 66); b. children from the influence of pornography (Article 67A), c. children who are victims of pornography (Article 67B); d. child victims of abduction, sale and/or trafficking (Article 68); and child victims of sexual violence (Article 69A).

Schools that should provide protection and a safe place for children to gain education for victims, sometimes actually become unsafe places for children. KPAI noted some violations of children's rights in the field of education throughout 2018, victims of sexual violence in 2018 were dominated by boys (Malia, 2018). Perpetrators of sexual violence include sports teachers by molesting 16 junior high school students with a shared learning mode to the promise of giving supernatural powers to children, as happened in DKI Jakarta in January 2018 (Malia, 2018). In the city of Surabaya, in February 2018 as many as 65 elementary students became victims of sexual violence by teachers/homeroom teachers using a persuasion approach towards victims (Keminfo, 2017). Even though the threat of punishment has been exacerbated, in reality, cases of violence against children have increased; even in 2015 it was declared an emergency of sexual violence (Keminfo, 2017). 


\section{LITERATURE REVIEW}

\section{Children as Victims of Violent Crimes}

Schafer (2017) state explicitly that every potential individual human being is a victim, meaning that everyone without exception can be a victim. Likewise, children have the potential to become victims. The emphasis here is on victims in the sense of victims of violence in the form of violence. Because not all victims are caused by violence and not every violence is a crime. Like, a mother who yelled at her child for having dared to fight when admonished was violent, but not a crime. The purpose of the mother to yell is to make the child not fight when admonished, and that is intended so that children become better in the future.

Schafer (2017) states there are types of victims that are associated with accountability, there are 4 (four) types, namely: (a) unrelated victims, are those who do not have any relationship with the criminal unless the criminal has committed a crime against him. For example, victims of sexual violence are raped by people they do not know or have known. In this type the responsibility rests with the criminal; (b) provocative victims are those who do something to the perpetrators and consequently they become victims. For example, the victim intentionally provokes the offender's emotions by saying hurtful things, as a result, the offender's emotions and vents his frustration on the victim by committing unlawful acts. In this case, the victim is the main perpetrator. In this type, the responsibility lies with the two parties, namely the victim and the perpetrator; (c) precipitative victims are the behavior of victims who unwittingly encourage perpetrators to do evil. For example, victims who deliberately allow perpetrators to invite the perpetrators to play at the victim's house, even though the house is quiet. At that moment, the perpetrators' evil intentions appear, namely by deceiving the victims. In this case, the responsibility lies with the offender; (d) biologically weak victims are those who have certain physical and mental forms that encourage people to commit crimes against them, such as children, old age, and women, people who are physically and mentally disabled, because the condition makes the perpetrators have the intention to commit a crime.

\section{Violence against Children}

According to Anwar (1981) violence as a means of coercion, a means that results in resistance from people who are forced to become weak. Not infrequently the result of such violence results in minor injuries or serious injuries of the victims, some even end in the death of the victim.

Herkuntanto, (2000), an act said as violence against children, can be seen in its characteristics as follows: a. actions taken can be physical or non-physical (psychological); b. the action is carried out actively (by doing) or passively (not doing); c. the action is desired (chill) by the perpetrator; d. Such actions have consequences/potential adverse consequences for victims (physical or psychological) that the victim does not want (for example death of the victim, or injury to the victim).

\section{Factors That Cause Children Become Victims of Violence}

In the Regulation of the Minister of State for the Empowerment of Women and Child Protection of the Republic of Indonesia Number 02 of 2011 concerning Guidelines for the Management of Children Victims of Violence, explained the factors causing children to be victims of violence, are: a. poverty factor; b. education factor; c. socio-cultural factors; $d$. factors in the use of advances in information technology (IT) and communication without adult supervision; e. abusive behavior factors; and f. environmental factor.

Some things that affect the involvement of children in the family economy include a. the child is considered an asset. In some community members, children are still used as family assets, so from early age children are required to help parents make a living. b. Waiver of children's rights. The lack of understanding of children's rights is right among some members of the community. As a result, the child was still considered a part that can be arranged with the will of his parents. c. Consumptive lifestyle/lifestyle. Fulfillment of consumerist lifestyles and cannot stand seeing other children have a luxurious lifestyle, tends to cause children to meet their needs in various ways.

In addition to economic factors, the lack of parental knowledge about children's rights and parenting causes parents to abuse children. For example, parents who always beat their children if children do not want to obey their parents' orders. Socio-cultural factors can also be a factor causing violence in children. Various acts of violence experienced by children, often caused by an act of violence that is considered normal during society. For example, the coercive measures carried out by parents/customs for children to get married at the age of din. Likewise advances 
in science and technology such as the ease of accessing the internet without the supervision of parents/community/government so that various child pornography shows that circulate on the internet cannot be monitored by parents. Likewise with the screening of films that generally contain elements of violence in various television broadcasts and print media which result in children doing and imitating the scene.

\section{Children's Rights as Victims}

Declaration of basic principles of justice for victims of crime and abuse of power, states some of the basic rights of victims of crime that should be guaranteed and protected by the state, including a). The right of the victim to the availability of a justice mechanism and obtain compensation immediately; b). The victim's right to information regarding her rights including in seeking compensation and obtaining information on the progress of the ongoing legal process including compensation; c). The right of the victim to express her views and give opinions; d). The victim's right to the availability of assistance/support during the legal process; e). The victim's right to protection from harassment/intimidation/reprisal from the perpetrator, protection of personal freedom and safety of both personal and family; f). The victim's right to a quick and simple justice mechanism/process/absence of delay.

The rule of law against children as victims is not only a rule that guarantees the rights of children as victims of crime in Indonesia, but several countries also regulate it, such as the United States and Britain. Some of the legal rules can be seen in the law as follows:

\section{a. Children's Rights as Victims in Legislation.}

In Indonesia, in regulating the rights of children as victims have adopted the principles and rights of victims as stated in the Declaration of Justice for victims in several large countries such as in the United States and the United Kingdom, as well as trends in the development of law at the international level. However, the challenge in implementing these rights is how the implementation of the rights of victims of crime is improved in practice and law enforcement.

The criminal procedure code regarding victims is regulated in several articles as follows. a). the right of the victim to report (Article 108 paragraph 1) regulating that every person who experiences, sees, witnesses and or becomes a victim of an event that constitutes a criminal offense has the right to submit a report or complaint to the investigator and or investigator, both oral and written. b). justice interests of a victim submitting expert statements, (Article 133 paragraph 1); c). in the case where it is necessary that for postmortem examination it is no longer possible to be avoided, the investigator must first notify the victim's family (Article 134 paragraph 1); d). In the case of the victim being questioned, (Article 160 paragraph 1 b), the testimony of the victim is the witness who is first heard.

\section{b. Children's Rights as Victims in the Trial Process}

The rights of children as victims in the trial process are divided into three parts, namely: the rights of children as victims before the trial, the rights of children as victims during the trial, and the rights of children as victims after the trial (Gultom, 2014). The development of children's rights in the criminal justice process is a result of the interaction of children with families, the community, law enforcement, and mutual influence. Families, communities and law enforcement need to raise awareness of the protection and care for children's rights for the welfare of children.

\section{Protection of Children as Victims in the Criminal Justice System}

Victims in the criminal justice system are those who seek justice which has often been neglected. Victims of criminal acts and the public are automatically represented by the state by prosecuting and imposing penalties on the perpetrators. This according to Kerper (2010) is different from ancient times, where victims or their families can immediately ask for compensation or retaliation from the perpetrators. Victim protection arrangements, especially in the Indonesian criminal justice system, have not shown a clear pattern (Shopia, 2014). In the current positive criminal law, the protection of more victims constitutes abstract protection or indirect protection (Arif (1996). Protection of victims in the form of material compensation can be sued directly to the perpetrators of the crime, whereas compensation is immaterial if the perpetrator is unable, charged to the country.

In Indonesia, awareness of the rights of victims of crime and other violations of the law is still far from victims' expectations. A strong commitment from the state as the holder of the security control and citizen protection 
authority is needed. The state is responsible for fulfilling the rights of victims and all victims' suffering. The experience faced by crime victims and their companions with law enforcement officers proves that Indonesia's criminal justice system still leaves some problems. Law enforcement officials have not been oriented to the experiences and interests of victims, both in the process in the police, prosecutors' offices and testifying in court. One thing that cannot be denied and is a longstanding criticism of the dissatisfaction of the current system is that there is no place for victims to participate directly. The presence of the concept of restorative justice seems to be the key to reopening the position of the victim in the settlement of a criminal case and offering different views and approaches in understanding and handling a crime. Restorative justice, the meaning of a crime is the same as the view of criminal law in general. In the restorative justice approach, the victim is the main thing that receives a direct impact on the occurrence of a crime. Therefore there is an obligation of the offender to fix the relationship damage due to a criminal act.

One effective method of enacting the principle of simple justice quickly and low cost in criminal justice is to apply the concept of restorative justice, both at the first instance, appeal and appeal at the Supreme Court. The measure of justice in restorative justice is no longer based on the equal retribution of the victim to the offender (physical, psychological, or punishment), but the painful act is cured by giving support to the victim and requiring the offender to be responsible, with the help of family and community when needed. Indonesia has adopted the concept of restorative justice in juvenile justice processes. This is considered to better guarantee the fulfillment of a sense of justice between victims and perpetrators.

In ordinary criminal proceedings, victims feel very little justice because the Prosecutor as the public prosecutor as a representative of the state emphasizes retributive justice with demands for criminal justice and restitutive justice which emphasizes more justice on the provision of compensation which only gives authority to the state delegated to the enforcement apparatus laws such as police, prosecutors and judges, while justice for victims is very minimal.

This restorative justice approach emphasizes the responsibility of the perpetrators as an effort in restoring the suffering of the victims without ignoring the interests of rehabilitation of the perpetrators and creating and maintaining public order (Shopia,2014). The restorative justice approach is a paradigm that aims to address dissatisfaction with the work of the existing criminal justice system. This approach is used as a strategy frame for handling criminal cases. The application of the concept of restorative justice in the courts of the first instance up to the Supreme Court is considered quite effective in reducing the pile of cases of the supreme judges.

The restorative justice approach is assumed to be the most recent shift from the various models and mechanisms that work in the criminal justice system in handling criminal cases today. The United Nations, through the outlined basic principles, considers that a restorative justice approach is an approach that can be used in a rational criminal justice system.

After going through a long journey of discussion about the protection of victims of crime, to be able to realize protection for victims, especially children who are victims of sexual violence, the participation of various parties is needed so that what is the demand for justice for victims can be realized. The parties that are expected to work together in providing legal protection to the child are law enforcers and their officials, which include the police, prosecutors, judiciary, advocates, and other related institutions such as LPSK, KPAI, and LBH and so on. The parties who are competent in providing such protection have an important role in providing legal protection to children as victims who have the following duties.

1) Police

Legal protection for victims is given during the examination process, which is from the time of the investigation to the investigation, which is in the form of examining witnesses and/or victims' information, examining evidence related to criminal acts experienced by the victim, including accompanying the victim at the time of medical examination and request for post mortem report from the hospital, the process of criminal acts includes arresting suspected offenders to detaining suspected offenders if they are deemed to have met the elements of a criminal offense.

\section{2) Prosecutors' Office}

Legal protection given to victims is to sue the defendant following his guilt as regulated in the law. By using the 
defendant according to the defendant's mistake, at least makes the victim feel safe and protected because of the presence of the state to protect the rights of children as victims.

\section{3) Justice}

The protection given by the judge to the victim is to give a fair verdict following the act/mistake of the culprit and following applicable law. Judges must pay attention, in cases with child victims, not only criminal sanctions (prison/confinement) and fines imposed on the perpetrators, but there is an obligation of the perpetrators to assist the victim and his family as a form of sympathy for the perpetrators of the suffering felt by the victim or his family due to the perpetrators of crimes, including costs for initial treatment or recovery of physical or psychological condition of the victim in the future. Besides, the judge in his decision, at the request of the victim and his family can provide additional sanctions on the offender, namely the obligation of the offender to provide restitution to the victim. If the offender is unable, the victim is entitled to compensation from the state.

4) Advocate

Advocates in Law Number 18 the Year 2003 concerning Advocates are people who work in providing legal services, both inside and outside the court, who fulfill the requirements based on the provisions of this law (Article 1 number 1). Whereas what is meant by legal services are services provided by lawyers in the form of providing legal consultation, legal assistance, exercising power, representing, assisting, defending, and carrying out other legal actions for the client's legal interests.

\section{5) Integrated Service Center for Empowering Women and Children (P2TP2A).}

P2TP2A is an integrated activity center that provides services for women and children victims of violence. P2TP2A is an integrated service center in efforts to empower women in various fields of development and protection of women and children from various forms of discrimination and acts of violence, formed by the government or community-based, can be a referral center, legal consultation center, reproductive health consultation center, integrated crisis center (PKT), trauma recovery center, integrated service center (PPT), women's crisis management center, shelter, and others.

6) The protection provided includes medical services, legal services, psychological services, and social rehabilitation services. While the experts involved in P2TP2A include psychologists, doctors / medical personnel, legal experts, social workers, and religious experts.

P2TP2A in carrying out its functions can make referrals to provide follow-up services to women and children who experience problems with categories of services related to law enforcement. Legal aid services include legal consultation, assistance, and defense by officers in charge of the law.

\section{7) Witness and Victim Protection Agency (LPSK)}

LPSK is an independent institution established and is responsible for handling the provision of protection and assistance to Witnesses and Victims based on their duties and authorities as stipulated in the Act. LPSK aims to fight for the rights of witnesses and victims in the criminal justice process. In realizing this goal, LPSK cooperated with several agencies, one of which was the Indonesian national police.

The protection provided by LPSK in the form of assistance and psychological services. Assistance here includes when giving information at the police level to the court. Providing security and comfort for witnesses and/or child victims of sexual violence, in the process of investigation, investigation, and trial. The forms of assistance provided by LPSK are assistance, relocation to safe houses, monitoring of circumstances and cases that witnesses and/or child victims are undergoing until the process is completed (judge's decision), as well as helping to submit requests for compensation, restitution, and assistance.

8) Legal Aid

Legal aid according to Article 1 number 1 of Law Number 16 of 2011 concerning Legal Aid is legal services provided by legal aid providers for free to legal aid recipients. The implementation of legal aid aims to: a. guarantee and fulfill the right for legal aid recipients to get access to justice, b. realize the constitutional rights of all citizens following the principle of equality in law, c. guaranteeing the certainty that legal aid will be carried out evenly throughout the territory of the Republic of Indonesia, and. d. realizing an effective, efficient and accountable court. (article 3 of Law Number 16 of 2011). 


\section{Compensation, Restitution, and Provision of Aid to Victims of Crime}

Article 7 (1) Law Number 13 of 2006 concerning the protection of witnesses and victims, regulating victims through LPSK has the right to submit to the court in the form of a. the right to compensation in cases of gross human rights violations; and $b$. the right to restitution or compensation which is the responsibility of the perpetrators of crime, then as an implementation regulation of this provision is government regulation number 44 of 2008 concerning the granting of compensation, restitution, and assistance to witnesses and victims and has been updated with government regulation number 7 of 2018 concerning provision of compensation, restitution, and assistance to witnesses and victims.

Article 98 to Article 101 of the criminal procedure code regulates the filing of claims for compensation, in connection with that the parties need to pay attention to the following matters. 1). Losses incurred must be caused by the crime itself, meaning that no losses may be incurred by other criminal acts which are used as the basis for claims for compensation. 2). Losses caused by criminal acts or other people who suffer losses (victims) as a direct result of these criminal acts. 3). the claim for compensation resulting from the criminal offense is addressed to the perpetrator (the defendant). 4). Claims for compensation submitted to the defendant were combined or examined and decided together at the same time in the examination and decision of the criminal case that was charged to the defendant and in the form of a decision.

Compensation, according to Schafer (2017) is defined as payment by the state to victims who have suffered. Compensation according to Article 1 number 4 of government regulation number 44 of 2008 concerning the provision of compensation, restitution, and assistance to witnesses and victims, is intended as "compensation given by the state because the perpetrators are unable to provide full compensation which is their responsibility".

Compensation in Article 1 number 4 of government regulation No. 7 of 2018 concerning the provision of compensation, restitution, and assistance to witnesses and victims are defined as "compensation provided by the State because the perpetrator is unable to provide full compensation for which he is responsible for the victim or his family". The new provisions of this rule, namely government regulation No. 7 of 2018 governing this compensation, there are a few additional sentences that give more emphasis to which compensation is given, namely the sentence "to the victim or his family".

Restitution is the payment of compensation which is charged to the perpetrator of a crime for the victim. Restitution according to Article 1 number 13 of Law No. 21 of 2007 concerning the eradication of trafficking in persons is "payment of compensation which is charged to the perpetrator based on a court decision that has permanent legal force for material and/or immaterial losses suffered by the victim or his heir."

Article 1 number 5 PP No. 44 of 2008 regulates, restitution is "compensation given to victims or their families by perpetrators or third parties, can be in the form of a return of the property, payment of compensation for loss or suffering, or reimbursement for certain actions". There is a change in this provision in Article 1 number 5 PP No. 7 of 2018, according to this regulation, what is meant by Restitution is "compensation given to victims or their families by perpetrators or third parties". The new provisions on restitution do not regulate the form of restitution that can be given to victims, namely the omission of the sentence "can be in the form of returning property, compensation for loss or suffering, or reimbursement for certain acts".

The use of the term "assistance" in Article 1 number 7 PP No. 44 of 2008 implies services provided to victims and/or witnesses by LPSK in the form of medical assistance and psycho-social rehabilitation assistance. In PP No. 7 of 2018, the meaning of assistance stipulated in Article 1 number 7 is defined as "services provided to witnesses and / or victims by LPSK in the form of medical assistance and psycho-social and psychological rehabilitation assistance". In this new regulation, it seems that this assistance emphasizes first witnesses before victims, and there are additional aspects of 'psychological"

According to Weda (2017) the need for payment of compensation to victims (crime), the State is the most obliged to pay attention to the condition of its citizens. The state through its apparatus is obliged to maintain public order and security. Therefore, crimes that occur are the responsibility of the state. That is, the emergence of victims of crime is the responsibility of the state. Weda (2017) quoted Kunter's opinion, which reminded that victims have the right to claim the state. 
Article 7 paragraph (3) of Law No. 31 of 2014 concerning Amendments to Law Number 13 of 2006 concerning Protection of Witnesses and Victims, the application for Restitution can be done in 2 ways, namely: a. before a court decision that has obtained permanent legal force; or $b$. after a court decision that has obtained permanent legal force, which is made through the LPSK. If a request for restitution is submitted before a court decision which has obtained permanent legal force, LPSK may submit restitution to the public prosecutor to be included in the claim (Article 7 paragraph 4).

A request for restitution is submitted after a court decision has obtained permanent legal force, LPSK can submit restitution to the court for a decision. (Article 7 paragraph 5). If the victim of crime dies, Restitution is given to the Victim's Family who is the Victim's heirs. (Article 7 paragraph 6).

Further provisions regarding the procedure for requesting and granting compensation and restitution as referred to in Article 7 and Article 7A above, are regulated by government regulation (Article 7B), namely government regulation (PP) Number 44 of 2008 concerning granting compensation, restitution, and assistance to victim-witnesses.

Looking at the conditions and situations that occur, with consideration to implement the provisions of Article 7 paragraph (3) and Article 34 paragraph (3) of Law Number 13 of 2006 concerning Protection of Witnesses and Victims which has been amended by Law Number 31 of 2014 concerning amendment to law number 13 Year 2016 concerning Witness Protection, the government considers it necessary to replace Government Regulation (PP) Number 44 of 2008 concerning provision of compensation, restitution, and assistance to victim-witnesses.

Based on these considerations, on March 1, 2018, President Joko Widodo had signed Government Regulation No. 7 of 2018 concerning Provision of Compensation, Restitution, and Assistance to Victim Witnesses. According to this PP, victims of gross human rights violations are entitled to Compensation, the application of which is submitted by the victim, family or proxy to the court through the witness and victim protection agency (Article 2).

Restitution is the right of a victim of a criminal offense (Article 19 PP No.7 of 2018). An application for restitution is submitted by the victim, family or proxy (Article 19 paragraph (2). The form of restitution which is the victim's right can be in the form of a. Compensation for loss of wealth or income; directly as a result of a criminal act, and/or c. reimbursement of medical and/or psychological care costs Providing assistance, given to witnesses and/or victims of gross human rights violations, criminal acts of terrorism, criminal acts of trafficking in persons, acts of torture, criminal acts of sexual violence, and severe torture are entitled to receive assistance (Article 37 paragraph (1).

Victims' rights are regulated in PP No. 7 of 2018 concerning the provision of compensation, restitution, and assistance to victim-witnesses, which are as follows. For compensation, it is the right of victims of gross human rights violations granted by the State, at state expense, victims who are entitled to compensation are victims of gross human rights violations (Article 2 paragraph number (1). Request to obtain compensation is submitted by the victim, family or their attorney (Article 2 paragraph (2). Request to obtain compensation shall be submitted in writing in the Indonesian language on sufficiently stamped paper to the court through LPSK (article 2 paragraphs (3). Submission of a request for compensation can be made when investigating human rights violations which are severe or before being read by the prosecutor (Article 3).

If the compensation request is declared complete, according to this pp, lpsk immediately conducts a substantive examination (article 6) and can request information from the victim, family, or his attorney and other relevant parties (Article 7). The results of the examination of the substance referred to, according to this PP, are determined by the LPSK decision, accompanied by its consideration, and recommendations to grant or reject the request for compensation to the attorney general (Article 10). Furthermore, the Attorney General included the request for compensation along with the decision and consideration of LPSK in its claim (Article 11).

The human rights court checks and decides on the Compensation request following the provisions of the legislation, (Article 13 paragraph (1).) Furthermore, the attorney general carries out a human rights court decision which includes the provision of compensation by submitting a copy of the court's decision to LPSK no later than 7 (seven) days from the receipt of a court decision and LPSK submits a copy of the court decision referred to the victim, family or his proxy no later than 7 (seven) days after the copy of the court decision is received (Article 13 paragraph (4). 
LPSK carries out the granting of compensation based on the decision of the human rights court as referred to no later than 30 (thirty) days from the date the copy of the court decision is received by LPSK, "said Article 13 paragraph (4) of this PP. Further provisions regarding the procedure for granting and reporting compensation, according to this PP, are regulated by LPSK Regulation.

\section{The Role of the Witness and Victim Protection Agency (LPSK) in Protecting Victims}

The existence of a fair criminal trial is a demand and basic principle of universal human rights and the characteristics of a democratic state (Syamsuddin, 2006). The smoothness and success of a criminal justice process are highly dependent on the evidence that has been successfully presented in court. One of the evidence that can facilitate and determine the success of the criminal justice process is the testimony of witnesses and victims. The success of a criminal justice process is very dependent on the evidence that has been successfully revealed or found. In the trial process, especially concerning Witnesses, many cases were not revealed due to the absence of Witnesses who could support law enforcement duties. The existence of Witnesses and Victims is a very decisive element in the criminal justice process. The presence of witnesses and victims in the criminal justice process has so far received little attention from the public and law enforcement.

Cases that are not revealed and are not resolved are mostly caused by witnesses and victims afraid to give testimony to law enforcement because they are threatened by certain parties who feel disturbed if their evil deeds are revealed and must deal with the authorities. Therefore, all methods are used so that witnesses and victims do not dare to testify and drag him to court.

Legal protection and security guarantees for everyone who knows or discovers something that can help uncover a crime are necessary but because of the witness's fear if he reports an event that he sees or knows makes a case difficult to disclose. Therefore it is necessary to foster community participation to help law enforcement in uncovering criminal acts. There is a guarantee of legal protection and security for people who witness an event that violates the law is expected to create a situation that allows people to no longer feel afraid to report a crime that is known to law enforcement because they are worried or afraid that their lives are threatened by certain parties.

Based on the principle of equality before the law which is one of the characteristics of the rule of law, witnesses and victims in the criminal justice process must be guaranteed legal protection. The subject matter of the matter stipulated in the Law concerning the Protection of Witnesses and Victims includes a. Protection and rights of Witnesses and Victims; b. Witness and Victim Protection Agency; c. Terms and procedures for providing protection and assistance; and D. Criminal provisions.

Seeing the importance of better protection for witnesses and victims, Law Number 13 of 2006 concerning Witness and Victim Protection was amended by Law of the Republic of Indonesia Number 31 of 2014 concerning Amendment to Law Number 13 of 2006 concerning Witness Protection and victim. This Law shall come into force when it is promulgated (Article 11), namely October 17, 2014, by the Minister of Law and Human Rights of the Republic of Indonesia, Amir Syamsudin.

The Witness and Victim Protection Agency, which was established based on Law No. 13 of 2006, has a very important role in law enforcement and handling human rights violations. The development of the current criminal justice system is not only oriented towards the perpetrators but also oriented towards the interests of the Witnesses and Victims. Therefore, the LPSK institution must be developed and strengthened so that in carrying out its duties, functions, and authorities it can be synergistic with the duties, functions, and authority of law enforcement agencies within the criminal justice system.

The existence of Witnesses and Victims is crucial in the disclosure of criminal acts in the criminal justice process. Therefore, the protection of witnesses and victims is given at all stages of the criminal justice process. Provisions regarding legal subjects protected in this law are expanded in line with legal developments in society.

In addition to witnesses and victims, other parties also have a large contribution to uncover certain criminal acts, namely witness perpetrators (justice collaborators), whistleblowers and experts, including people who can provide information relating to a criminal case. Although he has not heard it himself, he has not seen it himself, and he has not experienced it himself, as long as the person's statement is related to a crime so that they need to be given protection. The aforementioned specific criminal offenses namely the gross violation of human rights, the criminal 
act of corruption, the crime of money laundering, the criminal act of terrorism, the crime of trafficking in persons, the criminal act of narcotics, the criminal act of psychotropic, the criminal act of sexual acts against children, and the act of other crimes that result in the position of witness and/or victim are faced with a very life-threatening situation.

Based on the development of the substance above, there appear to be some significant weaknesses in the implementation of Law Number 13 of 2006 concerning the protection of witnesses and victims, specifically regarding: a). insufficient institutions to support the duties and functions of LPSK in providing Protection for Witnesses and Victims; b0. The limited authority regarding the substance of the elaboration of the duties and functions of the LPSK which has implications for the quality of service delivery of Witness Protection, Victim, Witness Actors, Reporters, and experts; c0. Interagency coordination in the implementation of the granting of Compensation and Restitution; and d). Protection of children in conflict with the law.

From these weaknesses, it is necessary to change the regulation on witness and victim protection in the Law on Amendment to Law Number 13 of 2006 concerning Protection of Witnesses and Victims, which regulates, among others: 1). strengthening the LPSK institutions, including increasing the secretariat to a general secretariat and the formation of an advisory board; 2). strengthening the authority of LPSK; 3). extension of the subject of protection; 4). expansion of protection services for victims; 5). increasing cooperation and coordination between institutions; 6). the awarding and special handling given to Acting Witnesses; 7). The mechanism for replacing LPSK members between times; 8). amendments to criminal provisions, including criminal offenses committed by corporations.

\section{RESEARCH METHODS}

This research is a case of sexual violence with child victims committed by adults and children and has been legally processed through court proceedings. The legal basis used to conduct the case analysis examined includes the Criminal Code; UU no. 23 of 2002 concerning Child Protection, along with amendments namely Law No.35 of 2014, Law No.17 of 2016, Law No.13 of 2006 concerning Protection of Witnesses and Victims; Law Number 31 Year 2014, PP No. 44 of 2008 concerning the Granting of Compensation, Restitution and Assistance to Witnesses and Victims, as well as their derivative regulations namely PP No.44 of 2008 concerning Provision of Compensation, Restitution and Assistance to Witnesses and Victims, PP No. 07 of 2018 concerning Provision of Compensation, Restitution, and Assistance to Witnesses and Victims, PP No.17 of 2017 concerning Implementation of Restitution for Children Who Become Victims of Crime, PP No.7 of 2018 concerning Provision of Compensation, Restitution, and Assistance to Witnesses and Victims; UU no.3 of 1997 concerning Juvenile Justice; UU no.11 of 2012 concerning SPPA.

This research is more devoted to protecting victims of sexual violence, in the form of criminal punishment to the perpetrators as well as providing compensation by the state, granting restitution by the perpetrators, and providing assistance as compensation for victims as a result of sexual violence experienced by children, which was first done through a process of proof in the court. The approach taken is to use a normative legal research approach. This means that this research belongs to normative juridical research, which is related to two main aspects, namely the formation of law and the application of law (Simatupang, 2011). This research will lead to aspects of the application of the law through articles in the law specifically relating to the protection of the rights of children victims of sexual violence. Furthermore, to prove the element of wrongdoing as the basis for punishment is based on Article 183 and 184 of the Criminal Procedure Code (KUHAP) which will be used as a basis for judges to impose criminal sanctions on the perpetrators, whether in the form of imprisonment, fines or granting compensation, restitution or assisting the victim, if indeed the defendant's mistakes cannot be proven then the judge will release the defendant from the snares of the law.

In terms of form, this research is directed as an evaluative study that assesses the content of the laws and regulations related to the process of proving the existence of an element of wrongdoing, the aim of punishing with the protection of children as victims of sexual violence. By considering this type of research, the data used in this study are secondary data, which includes primary legal material in the form of legislation. The rules relating to acts of sexual violence that make children victims are used several rules, namely: in the relationship of victim protection used Number 23 of 2002 concerning Child Protection; Law Number 23 of 2004 concerning the Elimination of Domestic Violence; Law Number 21 of 2007 concerning Eradication of Trafficking in Persons; Law Number 35 of 2014 concerning Amendments to Law Number 23 of 2002 concerning Child Protection. Law number 17 of 2016 
concerning the stipulation of Government Regulations instead of Law Number 1 of 2016 concerning the Second Amendment to Law Number 23 of 2002 concerning Child Protection Into the Act, along with its implementing regulations and Act Number 13 of 2006 concerning Protection of Witnesses and Victims along with the rules for amendment namely Law Number 31 of 2014 concerning Amendments to Law Number 13 of 2006 concerning Protection of Witnesses and Victims along with their derivative rules such as Government Regulation Number 44 of 2008 concerning Provision of Compensation, Restitution, and Assistance to Witnesses and Victims that have been amended by Government Regulation No.7 of 2018 concerning Compensation, Restitution and Assistance to Witnesses and Victims promulgated on March 5, 2018, by the Minister of Law and Human Rights.

Furthermore, related to the evidence as a basis for punishment, Law No. 8 of 1981 concerning the Criminal Procedure Code is used. Whereas in the case of children involved as perpetrators the rules used in Law Number 1 of 1946 concerning the Criminal Code; Law Number 3 of 1997 (for cases that occurred before the entry into force of Law Number 11 of 2012 concerning the Child Criminal Justice System), Law Number 11 of 2012 concerning the Child Criminal Justice System.

This research also uses secondary legal materials which include various books, papers both in the form of published journals that are related to the protection of victims of sexual violence, as well as tertiary legal materials such as legal dictionaries, the internet and so on. In addition to the legal material above, to obtain maximum results, interviews were conducted with informants who are related to this writing, including PPA police who specifically handle cases of children, prosecutors, judges, advocates who have handled cases of sexual violence with child victims, as well as agencies that have concern for children's problems such as LPSK, KPAI. From the data and legal materials collected, then an analysis of the results of the study was carried out, and the construction of the data was carried out qualitatively, emphasizing the aspect of protection of children as victims of sexual violence.

Some of the assumptions put forward in this paper are as follows.

1. Placing the interests of children who are victims of sexual violence as a top priority in the law enforcement process gives the meaning that the law is in favor of the victim. This is because the essence of the protection of victims has a very important role and benefits in the recovery of physical and psychological conditions of victims after sexual violence they experience.

2. The process of law enforcement in the criminal justice system that occurs in practice so far tends to side with the perpetrators, not the victims, so that it has not given a place for children as victims of sexual violence to get justice.

3. Applying appropriate legal rules through an integrated criminal justice system and based on the principle of justice that upholds morals will provide benefits in protecting children as victims of sexual violence.

\section{RESEARCH RESULTS AND DISCUSSION}

\section{Description of Sexual Violence against Children in DKI Jakarta and Bekasi.}

The Special Capital Region of Jakarta (DKI Jakarta) covers 5 (five) regions, namely, Central Jakarta, East Jakarta, South Jakarta, West Jakarta, and North Jakarta, are areas with heterogeneous populations, because they consist of various ethnic groups, races, and religions and culture in Indonesia. The population of DKI Jakarta has reached 10.6 million people (BPS, 2019). while Bekasi is an area bordering Jakarta on the east side, along with the times, as an area close to the capital, Bekasi has experienced various changes in the progress of development as well as facilities and infrastructure in various government and private sectors which are almost evenly distributed throughout the region. In addition to the progress of various sectors in DKI Jakarta and Bekasi, the development of crime has also increased, so has the crime that threatens the safety of children to become objects of sexual violence.

The rise of cases of sexual violence against children raises the concerns of parents because acts of sexual violence can occur at anytime and anywhere, both in the private sphere (home environment) and the public sphere (public places) such as public toilets, security posts, and so on. Where there is an opportunity, the child is threatened to be victimized. Protection and supervision of the existence of children are needed, whether by family, community or country. In the event of sexual violence against children, various forms of protection for children must continue to be provided.

Dissemination of the knowledge of the dangers of free sex to children through outreach to schools and the dissemination of activities outside of school are prevention efforts that can be done by various parties to be able to 
help reduce the level of sexual violence on children. To provide an overview of the rampant cases of sexual violence against children, it can be seen data on cases of children who are victims of sexual violence that occurred between 2011 and 2017 issued by the Indonesian Child Protection Commission.

\section{Data on Cases of Children Victims of Sexual Violence}

Based on data obtained from the Indonesian Child Protection Commission (KPAI), the forms of sexual violence crimes experienced by children as victims between 2011 and 2017 include a. 418 cases of children who were victims of sexual violence through online; b. children as victims of sexual violence in the form of rape, fornication, sodomy (pedophilia) in 2171 cases; c. Children as victims of prostitution online as many as 558 cases, and d. 400 children as victims of commercial sexual exploitation of children. In detail, the data is described as follows. In 2011 there were 216 cases, in 2012 there were 412 cases, in 2013 there were 343 cases, in 2014 there were 656 cases, in 2015 there were 218 cases, in 2016 there were 192 cases, and in 2017 there were 134 cases. From the data of cases of sexual violence that occurred from 2011 to 2017, 2014 showed very prominent case data compared to the years before and afterward. For more details can be seen in Table 1 below:

Table 1. Data on Child Complaints Cases Based on Child Protection Clusters Indonesian Child Protection Commission 2011-2017

\begin{tabular}{|l|r|r|r|r|r|r|r|r|}
\hline $\begin{array}{c}\text { Protection Case } \\
\text { Children as Victims }\end{array}$ & $\mathbf{2 0 1 1}$ & $\mathbf{2 0 1 2}$ & $\mathbf{2 0 1 3}$ & $\mathbf{2 0 1 4}$ & $\mathbf{2 0 1 5}$ & $\mathbf{2 0 1 6}$ & $\mathbf{2 0 1 7}$ & Total \\
\hline Child victims of sexual crime online & 17 & 11 & 23 & 53 & 133 & 112 & 69 & 418 \\
\hline $\begin{array}{l}\text { Children as victims of sexual violence } \\
\text { Rape, Sexual Abuse, Sodomy / } \\
\text { Pedophilia) }\end{array}$ & 216 & 412 & 343 & 656 & 218 & 192 & 134 & 2171 \\
\hline $\begin{array}{l}\text { Children as victims of online } \\
\text { prostitution }\end{array}$ & 16 & 27 & 60 & 83 & 177 & 112 & 83 & 558 \\
\hline $\begin{array}{l}\text { Children as victims of Commercial } \\
\text { Sexual Exploitation of Children } \\
\text { (CSEC) }\end{array}$ & 59 & 37 & 51 & 46 & 72 & 69 & 66 & 400 \\
\hline
\end{tabular}

Source: Data of the Indonesian Child Protection Commission 2017 Information and Complaints Data Section, processed 2018.

Children who are victims of sexual violence are at various ages, the perpetrators looking for the target of children do not look at his age, even children under five years old did not escape the target of predators of children to vent their sexual appetite. It can also occur perpetrators of sexual violence against children of the same sex with the offender. This shows that there is a wrong/distorted behavior of the perpetrators, namely same-sex enthusiasts.

Increased sexual violence against children shows that parents must take care of their children seriously; negligence of parents in looking after children is an opportunity or opportunity awaited by the offender to carry out his evil intentions. Parents who are too busy with their respective affairs for one reason or another even consider their affairs to be the most important; sometimes do not realize the condition of their children being troubled by being victims of sexual violence. It must be realized, not every child has sensitivity to what is happening to him, when in fact the child has become a victim of a crime of sexual violence. This is due to various reasons, among others, the age of children who are toddlers who do not know what has happened to him can only cry because of pain in his organs due to sexual violence experienced or fear when meeting with strangers or people who have made themselves an object sexual assault. Only then did the parents realize that their child had become a victim.

The state, through the law, has given severe criminal threats to the perpetrators of sexual violence as sanctions for their actions, their implementation being the duties and responsibilities of law enforcement officials following their respective functions as mandated by the law. Likewise, agencies that have the responsibility in protecting children such as KPAI, LPSK, Komnas HAM, and LBH and so on must be committed to being able to establish cooperation with law enforcement officials and the community to realize legal protection for children victims of sexual violence as well and maximally.

Parents and the public who dare to report to the authorities when they find out the child has been victimized by sexual violence is very meaningful in saving and protecting children, then the perpetrators can be legally 
processed to take responsibility for their actions. What happens to child victims of sexual violence must immediately be sought for protection, and do not let events just pass without reporting on the grounds the offender is the closest person, the offender is a public figure that must be respected and will become a family disgrace. If the parents of children who become victims or the public do not dare to report on sexual violence experienced by children, then it is possible for sexual offenders to rampant in search of prey.

Even though the case of sexual violence based on the data shows a fairly high number, but there are still many cases that might not be revealed because the victim or her family did not dare to report. Thus, the freer the perpetrators to carry out their evil actions to find prey for children to be made to satisfy their sexual desires without fear.

\section{Sexual Violence against Children in Special Capital Region of Jakarta}

Jakarta as the capital city of the Republic of Indonesia, with all the modernization and rapid technological advances, is often accompanied by negative impacts that hurt the community if not used properly. This can be seen in the influence of technological advances in the form of communication tools that are extremely fast in providing information to the public, by some people being abused, such as the inclusion of information that has sexual elements that can easily be seen by anyone so that it can stimulate people to do things negatively.

Jakarta cannot be denied that every event that happens will certainly be the spotlight of various communities throughout the country. Likewise, if there is a case of sexual violence by making children victims, because the influence of the news technology will quickly spread and become a conversation in the community. An unavoidable reality, in busyness and all the activities of the community, children who escaped from surveillance have been victims of sexual violence by irresponsible people who only seek sexual satisfaction alone without thinking about the suffering of the victim. Perpetrators of sexual violence who use children as victims not only adults but also children, those with all persuasion and even threats of violence or violence carry out their evil intentions that are forcing children to satisfy their sexual desires.

\section{Sexual Violence against Children in Bekasi}

The high case of sexual violence against children in Bekasi shows that Bekasi is one of the unsafe places for children. The National Commission for Child Protection (Komnas PA) mentions Bekasi is in an emergency of sexual crimes against children (Surjaya, 2017). In recent years several cases of sexual violence against children have been found in Bekasi. The data recorded, from the last five years of 2013 to 2017, the number of cases involving children has fluctuated. In 2013 there were 125 cases, in 2014 there were 105 cases, in 2015 there were 100 cases. Based on the records of the Bekasi City Government, cases of violence against children in Bekasi City increased in 2016 an increase of 27\% compared to 2015 (Noersativa, 2018). In 2016, a crime against children recorded 127 cases received by the government, which included 42 cases of sexual harassment, 24 cases of sexual intercourse, 11 cases of rape, and the rest were cases of violence against other children (physical violence, neglect, theft, care, and abortion).

The Bekasi City Women's Empowerment and Child Protection Agency (DPPPA) recorded 198 cases involving children in Bekasi during 2017 (Noersativa, 2018). From these data, the highest number of cases of sexual harassment are 67 cases, 24 cases of rape/fornication, the rest are other cases such as physical violence, struggle for child custody. This condition shows that cases of sexual violence against children show a very high number compared to other cases, which occurred in the Bekasi area. The socialization to schools is a prevention effort carried out by the child protection sector, the Women's Empowerment Agency and the Protection of Children and Family Planning (BP3 AKB) Bekasi City (Noersativa, 2018).

\section{DISCUSSION}

Based on the results of research based on interviews conducted directly or through questionnaires to informants (PPA police, prosecutors, judges, advocates. LPSK, KPAI), and analysis of cases of sexual violence against children in several court decisions between 2006 and 2016 which occurred in the Special Capital Region of Jakarta and Bekasi, the following results can be obtained:

1. PPA Informant's Opinion Related To The Factors That Cause, Safeguards, and Obstacles in Protecting Children Victims of Sexual Violence.

In providing an understanding of the factors causing children to be victims of sexual violence, efforts made 
International Journal of Humanities and Applied Social Science (IJHASS)

E-ISSN: 2471-7576

February 2020, Vol: 5, Issue: 2

E-mail: editor@ijhassnet.com

http://ijhassnet.com/

DOI: 10.33642/ijhass.v5n2p1

(C)enter for Promoting Education and Research (CPER) USA, www.cpernet.org

in protecting children as victims of sexual violence as well as obstacles in protecting children as victims of sexual violence, then the writing of this dissertation is requested by the police as the party directly involved in handling children as victims of sexual violence.

The selection of informants for law enforcement officers, the PPA police, is based on the consideration of the police as the front guard of law enforcement dealing directly with the victims, in this case, children who are victims of sexual violence. Informants were taken randomly at the Women's and Children's Services Unit (PPA) Police, including PPA units from several Polres and Polsek in DKI Jakarta and Bekasi, namely Central Jakarta Police, West Jakarta Police, Metro Bekasi City Police, Tanjung Priok Police Precincts, Tanjung Priok Police Precincts Cilincing, Ciracas Police Station, Tambora Police Station conducted between October and November 2018. The questionnaire was open-ended, which included the following questions: 1. Factors causing children to be victims of sexual violence; 2 . the efforts made by the police in protecting child victims of sexual violence as well as 3 . The obstacles faced by the police in protecting child victims of sexual violence, the following research findings are obtained.

\section{Factors That Cause Children Are Victims of Sexual Violence}

Based on the results of research on 10 PPA informants, about the factors that cause children to be victims of sexual violence, obtained answers that are quite diverse according to what they met when providing examination and assistance to victims of sexual violence. The PPA police answers to the questions raised regarding the factors causing children to be victims of sexual violence obtained the following answers.

Factors that caused children to become victims of sexual violence in the opinion of 10 PPA informants obtained quite diverse answers. Lack of supervision and protection of parents/family, the most dominant answer, where children have often left alone or care is left to others on the grounds of busy parents. The solitude of children is used as an opportunity for perpetrators to carry out their intentions for sexual violence against children. Moreover, seeing the situation of children who look afraid/tend to be timid, weak, and do not dare to fight when threatened, making it easier for perpetrators to carry out these evil intentions. Likewise, the victim's mistake in finding social partners, where children associate with friends who have too free lives, without ethical manners, do as they please without being prohibited, which is a negative environment and is not good for the victim.

In addition to the answers above, another factor that causes children to be victims of sexual violence is a child's lack of understanding of sexual subjects because parents do not teach them. Parents sometimes feel no need to tell about matters relating to sex because they feel that one day their children will naturally know about sexuality as the child grows, there are feelings of feeling uncomfortable or do not know how to convey to children about sexuality. This situation makes children less sensitive when they are touched by others when it leads to their sexuality. Thus the child is easily exploited by the perpetrators as an outlet for the sexual passions of those around who do have evil intentions towards the child. One of the informants' answers about the cause of children being victims of sexual violence which is quite surprising is that the perpetrators have been victims of sexual violence. Anger, disappointment buried perpetrators who during the age of children have been victims of sexual violence make the perpetrators have the potential to take revenge so that when there is an opportunity and no longer able to control themselves, the offender vents his intention to sexually abuse children. More information about the answers to these informants can be seen in Table. 2, this below:

Table 2. Factors That Cause Children Are Made Victims of Sexual Violence

\begin{tabular}{|c|c|}
\hline No & Description \\
\hline 1 & $\begin{array}{l}\text { Lack of supervision and protection of people/families, often left alone and care given to others makes opportunities for } \\
\text { perpetrators to sexually abuse children. }\end{array}$ \\
\hline 2 & Children tend to be timid, weak, do not dare to fight, so that when threatened by the offender immediately obey. \\
\hline 3 & Associating children who are too free with a negative environment and are not good for the victim. \\
\hline 4 & $\begin{array}{l}\text { Lack of teaching about sex, and the absence of parental notice so that children do not want to be touched certain parts of } \\
\text { their bodies by others (even if it's their siblings). }\end{array}$ \\
\hline 5 & The family is not harmonious so that makes children often leave the house. \\
\hline 6 & The nature of a child who is still innocent, so easily persuaded, seduced or lied to by others. \\
\hline 7 & Perpetrators have been victims of sexual violence so that the potential for sexual violence against children. \\
\hline 8 & $\begin{array}{l}\text { Excessive use of television and internet media, especially those that display multiple shows and images, is free to access } \\
\text { pornography on the internet. }\end{array}$ \\
\hline 9 & Lack of moral and religious education. \\
\hline 10 & Economic factors / economic crush so that children are easily lured. \\
\hline
\end{tabular}

Source: processed questionnaire data, 2018 


\section{Efforts to Protect Children Victims of Sexual Violence}

Based on the results of a study of 10 PPA informants, regarding the efforts made by the police in protecting children as victims of sexual violence, the following answers were obtained. PPA police as the frontline in the investigation process, in collaboration with certain institutions, to carry out the physical and psychological recovery of children who are victims of sexual violence. Likewise with counseling to schools, parents, the community both in the RT/Rw environment and other associations regarding the dangers of pornography and porno-action carried out in each Polres. Besides, for children who are victims of sexual violence and are in the process of litigation, a special service room (RPK) is established as a place for children's services, which provides special spaces, such as playrooms. Provide assistance from social workers to assist when conducting the investigation process. More information about the informant's answers can be seen in Table 3. As follows:

Table 3. Attempts to Treat Children Who Become Victims of Sexual Violence

\begin{tabular}{|c|l|}
\hline No & \multicolumn{1}{|c|}{ Description } \\
\hline 1 & $\begin{array}{l}\text { Collaborate with certain institutions and agencies to carry out the physical and } \\
\text { psychological recovery of victims. }\end{array}$ \\
\hline 2 & $\begin{array}{l}\text { Provide counseling to schools, parents, the community about the dangers of pornography } \\
\text { and porno-action in each district police station. }\end{array}$ \\
\hline 3 & $\begin{array}{l}\text { Establish a special service room (RPK) as a children's service area. Provide a special } \\
\text { room in the case process, such as a playroom, etc. }\end{array}$ \\
\hline 4 & Assist the social workers to assist during the investigation process. \\
\hline 5 & $\begin{array}{l}\text { Refer the child to the hospital for a medical / post mortem examination of the child as the } \\
\text { victim. }\end{array}$ \\
\hline 6 & $\begin{array}{l}\text { Establish a Women and Children Service Unit (PPA), from the Headquarters to Police, as } \\
\text { set out in the National Police Chief Regulation Number 10 of 2007. }\end{array}$ \\
\hline 7 & $\begin{array}{l}\text { Increase the number of Policewomen to approach the ideal ratio, so that Policewomen } \\
\text { become the front guard in handling child protection cases and improve the ability of } \\
\text { personnel in the investigation and handling of cases of sexual violence against women } \\
\text { and children. }\end{array}$ \\
\hline 8 & $\begin{array}{l}\text { Provide a convenient means of examination, so that children do not feel afraid / } \\
\text { traumatized by sexual violence. }\end{array}$ \\
\hline 9 & $\begin{array}{l}\text { Approach children so that children do not feel afraid and involve psychologists to help } \\
\text { restore the victim's condition. }\end{array}$ \\
\hline 10 & $\begin{array}{l}\text { Organizing seminars, workshops that aim to provide information about the provisions or } \\
\text { regulations relating to the issue of legal protection for children and how to prevent and } \\
\text { handle violations. }\end{array}$ \\
\hline
\end{tabular}

Source: processed questionnaire data, 2018

\section{Obstacles in the Protection of Children Victims of Sexual Violence}

Based on the results of a study of 10 PPA informants, about the obstacles faced by the police in protecting children as victims of sexual violence, the following answers were obtained. The difficulty experienced by PPA to get an explanation of events experienced by children because children are silent. Children do not want to talk during the examination process because they are still traumatized by the perpetrators' threats. Besides, the problem of funds or budget and accommodation available to deal with child victims of sexual violence which is still minimal is also one of the obstacles for the police in protecting children victims of sexual violence. Further informants' answers about the obstacles faced by the police in protecting children as victims of sexual violence can be seen in Table 4 , below: 


Table 4. Obstacles in Providing Protection for Children Victims of Sexual Violence
\begin{tabular}{|c|l|}
\hline No & \multicolumn{1}{c|}{ Description } \\
\hline 1 & $\begin{array}{l}\text { Difficult to get an explanation, because the child is silent. Children do not want to talk during the } \\
\text { examination process because they are still traumatized by the perpetrators' threats. }\end{array}$ \\
\hline 2 & Budget and accommodation are still minimal. \\
\hline 3 & $\begin{array}{l}\text { Parents do not want their children's cases to be appointed/reported on the grounds of shame. } \\
\text { Reporting parties are less pro-active towards the police. }\end{array}$ \\
\hline 4 & $\begin{array}{l}\text { The lack of hospitals that can do a post mortem. Not necessarily every hospital or the nearest Public } \\
\text { health center is willing and willing to provide a post mortem or a post mortem examination, only } \\
\text { designated hospitals / Public health center can issue a post mortem. If the post mortem is not } \\
\text { designated in the hospital, the investigator provides an application for medical advice. }\end{array}$ \\
\hline 5 & $\begin{array}{l}\text { Settlement of children's cases in a fairly short examination so that the police sometimes lack time. It } \\
\text { takes a long time for investigators to gather accurate evidence to uncover cases and appropriate } \\
\text { sanctions for perpetrators related to sexual violence against children. }\end{array}$ \\
\hline 6 & HR personnel and quality in the police are still minimal regarding the protection of victims. \\
\hline 7 & Reporting parties are slow or incomplete. \\
\hline 8 & $\begin{array}{l}\text { It takes a long time related to sexual violence in children given the nature of children who are afraid } \\
\text { of the sexual violence they experienced. }\end{array}$ \\
\hline 9 & $\begin{array}{l}\text { The victim's address is not clear, so when the police want to ask for information the victim has } \\
\text { difficulty. }\end{array}$ \\
\hline 10 & The difficulty of proof is because there is no clue because only witness testimony. \\
\hline
\end{tabular}

Source: processed questionnaire data, 2018

\section{Protection of Children Victims of Sexual Violence in the Criminal Justice System}

Protection of child victims of sexual violence requires handling using a multi-disciplinary approach, which includes sociological, cultural, legal, psychological, and so on. As a consequence of deviant acts committed by the community, criminal policies are needed as a legal consequence for the actions committed by the perpetrators. Criminal policy is a part of public policy that will formulate normative rules regarding punishment or actions of the State to ensure that perpetrators of criminal acts will not repeat acts against the law, this policy can involve the substance of the procedure, and the objectives to be achieved by the act of punishment (Arief, 2005).

According to Thomas and Znaniecky, that environment is socially organized, when conventional values and traditions are not transmitted from one generation to the next. This can be seen in the lives of children who are raised in rural areas with culture and customs that are still thick, then continue their education to a higher level to urban areas that are full of freedom of association, then, in the end, makes them familiar with liquor, and free sex (Alam and Ilyas, 2018) When children with a strong rural culture mingle with city life that is new to them with a variety of technological advances, making children who are not given proper education and supervision, will change their behavior, which sometimes deviates from the rule of law. But it all does not just happen, there must be a process that is learned by children from adults and the surrounding environment.

The study of social disorganization from Thomas and Znaniecky was subsequently developed by Park and Burgess, by introducing an ecological analysis of human society. Approach to examine human ecology, (human ecology), namely the interrelation between humans and their environment. (Nature and Ilyas, 2018). In their study Park and Burgess examined the characteristics of regions consisting of concentration zones. Each zone has its structure and organization, cultural characteristics and its inhabitants.

The society in which children grow and develop also has a very important role in protecting children, bearing in mind that children as the next generation of the nation are not only the responsibility of parents but also the community. Article 72 of Law Number 23 the Year 2003 concerning Child Protection accommodates community participation, namely: a. the community has the right to the broadest opportunity to play a role in protecting children; b. This role is carried out by individuals, child protection institutions, social institutions, educational institutions, religious institutions, business entities, and the mass media. If this role is carried out to the maximum, then the protection of children can be guaranteed its implementation.

In addition to protecting child victims of sexual violence from the multidisciplinary study above, the protection of child victims of sexual violence is also a shared responsibility of all parties, through an integrated criminal justice system, which includes the police, prosecutors, judges, advocates, but also must involve various 

synergy of several institutions will give more hope to the child victims of sexual violence and their families to get justice for the suffering they experience.

\section{Protection of Children Victims of Sexual Violence by the Police Women's and Children's Services Unit (PPA)}

Women's and Children's Services Unit (PPA) based on the Regulation of the Head of the Indonesian National Police Number. Pol: 10 of 2007 concerning the Organization and Work Procedure of the Women's and Children's Services Unit (PPA), is a unit that is tasked with providing services in the form of protection for women and children who are victims of crime and law enforcement against perpetrators (Article 1 number 1). Protection provided by the National Police at the time of examination from the investigation to the investigation stage, protection provided in the form of examination of witness and/or victim information, examination of evidence related to criminal acts experienced, including accompanying at the time of medical examination and request for post mortem report from the hospital, the process of criminal acts includes arresting suspected offenders to detaining suspected offenders if they are deemed to meet elements of a criminal offense.

There are currently twenty-six members of the Police PPA Police Unit who are BKO (Under Operational Control) at LPSK, four of whom are female police. The Polri member on duty is called the Pamwal Task Force, which is the Task Force for the Safeguarding of the Guard, which serves as the LPSK frontline in achieving the goals of the institution (Alam and Ilyas, 2018). This PPA unit police in carrying out their duties in collaboration with the Integrated Service Center for Empowering Women and Children (P2TP2A) which is an integrated center of activity that provides services for women and children victims of violence. The protection provided includes medical services, legal services, psychological and social rehabilitation.

The police guardian task force protects witnesses and/or victims of women and children to be safeguarded during the criminal proceedings they experience, or until the witness and/or victim feels safe there is no threat to him anymore. Often meet witnesses and/or victims who are difficult to work with, feel uncomfortable to be witnesses and / or victims and to continue the criminal process, this is caused by internal and external threats, peace efforts by the perpetrators, blindness education about the legal process in Indonesia so that witnesses and/or victims feel reluctant to continue the case. In examining victims a Special Service Room (RPK) is needed, which is a very important means of protecting children, but in reality in police stations, not all have it.

\section{Protection of Children Victims of Sexual Violence by Prosecutors}

The protection provided is to sue the defendant of sexual violence following applicable law. Based on the results of an interview with prosecutor Ricardo (2019). Regarding the protection of children who are victims of sexual violence, considering that children are God's creations that must be protected and protected as stipulated in the law if children experience sexual violence, the law must act as fairly as possible, meaning that the perpetrators must apply sanctions following applicable laws.

The prosecution is not only based on the perpetrators' mistakes but also has to consider the consequences that the child must suffer. Therefore, in his demands, the prosecutor as the public prosecutor does not merely sue the perpetrators with corporal punishment or fines but must also pay attention to other rules that protect victims, such as demands for compensation from the state, restitution from perpetrators and assistance to victims. The criminal prosecution of the offender in addition to being able to provide a deterrent effect on the defendant at least makes the child victim feel safe because of the presence of the state to protect his rights as a victim.

\section{Protection of Children Victims of Sexual Violence by Judges}

Judges following their authority are to render fair decisions following the actions of the convicted and the wrongdoers. Based on the results of interviews with Judge Informants (Sutrisno, 2019). related to the protection of child victims of sexual violence, as a judge who has a duty in law enforcement to get justice for justice seekers within the TNI and the Indonesian community, the task of law enforcement is realized in examining and adjudicating a case delegated by military prosecutors (Public Prosecutors), which takes place in a military court environment.

During his time as a Military Judge, he has only decided three cases of sexual violence against children (3 cases), namely in 2011 in the Military Court II-08 Jakarta and 2016 in the High Military Court III Surabaya (in the 
case of an appeal). The protection given as a judge is to examine and try the case (sexual violence) by giving the fairest justice to the victim, without neglecting justice for the perpetrators of the crime (balanced with the fault of the defendant). The severity of a sentence against a defendant is measured by the extent to which the defendant is proven to have committed the crime. The criminal conviction must be balanced with the defendant's guilt which is proven in the proof of the elements and background of the criminal act committed by the defendant.

In the case of military perpetrators, in addition to being sentenced to imprisonment and fines, there is also a very severe criminal sentence namely an additional crime "fired from military service" because the defendant will lose his status from a TNI soldier and become a civil society (losing his job as a TNI). Related to cases of sexual violence against children so far, as a judge always imprisonment is never below the minimum starch at and is followed by an additional sentence "fired from military service", therefore the judge believes the punishment is worthy and balanced with the mistakes/actions of the Defendant.

The basis for considerations used by judges in giving sentences to perpetrators of sexual violence against children is a. the actions of the defendant can be detrimental to the victim and his family both morally and materially because with this incident it would severely hit the victim's soul which would cause a prolonged trauma, b. the Defendant's actions were very inappropriate for a TNI soldier who was supposed to protect and protect the community, not the other way around, c. Defendant's actions are very contrary to the lives of soldiers who obey and obey the rule of law, both doctrine (Sapta Marga, Oath of Warriors or eight mandatory TNI), as well as applicable laws so that they must be separated from the lives of soldiers and fired from military service.

In convicting a criminal against a defendant, it is always followed by a criminal fine following Law Number 23 of 2002 concerning Child Protection. Regarding sanctions in giving something for treatment or recovery of the victim or his family, he never included it in the verdict, but in the trial, the judge always allowed the defendant to provide medical assistance that was agreed upon during the hearing (as a form of evidence that the defendant regretted his actions and was responsible for the actions.) but also saw the Defendant's abilities. Whereas the implementation of criminal fines which are always followed by confinement subsidiary for some months, this is left to the editor as the executor whether the defendant will pay the fines or add to the imprisonment for how much according to the verdict.

\section{Protection of Children Victims of Sexual Violence by Advocates}

Advocates as a profession in providing legal services have an important role in helping victims of sexual violence in obtaining assistance in every legal process. Moreover, if the victim is a child, special skills are needed to assist. The protection given by advocates of Advocates (Tompul, 2019) to clients (children) who are victims of sexual violence is done by assisting when the victim makes a post mortem, counseling to a psychologist (Pulih Foundation), opening a police report, the victim provides information before the investigator and brings a psychologist when a child victim of sexual violence states the District Police Station. Furthermore, advocates, fight for legal protection for children victims of sexual violence in the Court and seek to provide a deterrent effect for perpetrators.

Facts on the ground, child victims of sexual violence are often not accepted in the environment and even expelled from schools, what advocates do is a fight for children's rights, especially health and education rights by visiting the school and explaining children's rights.

\section{Protection of Children Victims of Sexual Violence by the Witness and Victim Protection Agency (LPSK)}

LPSK is an independent institution established and is responsible for handling the provision of protection and assistance to witnesses and victims based on their duties and authorities as stipulated in the law. LPSK aims to fight for the rights of witnesses and victims in the criminal justice process. In realizing this goal, LPSK cooperated with several agencies, one of which was the Indonesian National Police.

LPSK provides information and education about the legal process that witnesses and/or victims are supposed to undergo and also collaborates with doctors and psychologists to provide medical and psychological services as a result of criminal acts committed by perpetrators, especially witnesses and/or child victims who have special difficulties. LPSK provides services according to protected needs, and protection services provided can be in the form of Safe Houses, monitoring and assistance, these services are provided following the LPSK leadership's decision after analyzing threats to witnesses and/or victims. If the threat is considered high for witnesses and/or victims, it is 
necessary to provide a Safe House service, where the Protected Guard is guarded by the task force for 24 hours every day at the Safe House that has been provided, for moderate and low threats LPSK provides monitoring services, namely surveillance services or the monitoring carried out by the Satgaspamwal, an example of its activities, is monitoring the activities of the Protected at home or workplace and analyzing threats that might occur.

Furthermore, for assistance services, namely services provided by LPKS to witnesses and/or victims in the process of investigation, investigation to the examination of witnesses and/or victims' statements at the trial, this assistance service is carried out by the LPSK along with the staff responsible for his case (Case Manager). LPSK also helped submit a request for Compensation, Restitution, and Assistance. This is also the job of the staff responsible for his case (Case Manager).

LPSK welcomes the enactment of Government Regulation No.7 of 2018 concerning Provision of Compensation, Restitution and Assistance to Witnesses and Victims by the President on March 1, 2018, then. With this government regulation, it is expected to further strengthen witness protection and fulfillment of victims' rights, whereas, in the previous government regulation, namely Government Regulation No.44/2008 concerning Granting Compensation, Restitution, and Assistance to Witnesses and Victims, several obstacles and problems were found.

Law Number 13 of 2006 concerning Witness and Victim Protection has been amended by Act Number 31 of 2014 concerning Amendment to Law Number 13 of 2016 concerning Witness Protection has changed. Including the expansion of criminal acts where victims get priority protection. Amendments to the Witness and Victim Protection Act certainly must be supported by derivative rules, including government regulations, which can support the implementation of the Witness and Victim Protection Law.

Existing developments in this government regulation include a detailed breakdown of the components of restitution (compensation from perpetrators to victims), to the related expansion of victims of criminal offenses entitled to receive assistance. Regarding the detailed component of calculating restitution is considered important because it can be the legal basis for the amount of restitution submitted. Previously, there was a debate about the basic value of the amount of restitution calculated by LPSK, because it was considered that there was no clear basis. As a result, it is not uncommon for the amount to be reduced when sentenced, or even rejected by the judge.

Regarding self-help, if Government Regulation No.44/2008 can only be given to victims of gross human rights violations, in Government Regulation No.7/208 this assistance can also be given to victims of terrorism, human trafficking, torture, criminal acts of sexual violence and severe maltreatment. This is of course very important considering the victims of these crimes also need assistance in terms of medical, psychological, and social psycho services. This becomes the legal basis for LPSK if there is a witness or victim-witness protection that requires assistance. Of course, the expansion of the types of criminal acts for which victims can be assisted is very positive considering the trauma they experienced must, of course, be recovered including through relief efforts. LPSK is ready to carry out the mandate given by the PP because previously LPSK had also carried out the mandate of providing compensation, restitution, and assistance. LPSK also hopes that there will continue to be legal improvements in favor of witnesses and victims.

In its implementation, the role of LPSK in providing psychological assistance to the two clients handled by LPSK is children aged 10 (ten) years and 11 (eleven) years who are victims of sexual violence against children can be described as follows. Implementation of Government Regulation No.7 of 2018 concerning Provision of Compensation, Restitution, and Assistance to Victim Witnesses, some obstacles arise concerning restitution as victims are the absence of force, and there is a criminal formulation subsidized by confinement. Furthermore, Syahrial (2015) said, the Government Regulation Mechanism Number 43 the Year 2017 concerning the Implementation of Restitution for Children who are Victims of Crime has no confiscation of assets for restitution. There is a crime in trafficking in persons (TPPO) but there has never been confiscation of assets for restitution (Article 50). For example, in the case of sexual violence against children (13 years), against sexual assault perpetrators, the prosecutor asked the perpetrators of 5 (five) people to assist victims, for Rp 6,000,000 (six million rupiahs).

As an illustration of the calculation of the costs to be incurred by the victim and her family, Syahrial (2015) gave an example of two clients handled by LPSK, as follows. Information about the costs involved in the recovery process of victims of sexual violence is very important. This is because these costs become an important tool in the recovery of victims of sexual violence that must be borne by the victim and her family if the victim does not receive 
compensation, restitution or compensation for the results of sexual violence by the perpetrator. Based on the results of interviews with LPSK delivered by Martanto (2019), for cases of sexual violence against minors, related to the cost of recovery of victims in protecting victims of sexual violence in the form of compensation, restitution, and compensation to victims, so far it has not been able to realize.

In connection with efforts to protect victims of sexual violence, LPSK provides an overview of the psychological condition of victims and costs to be incurred in the recovery of victims' conditions involving the role of psychologists appointed by LPSK, namely two examples of cases handling clients (children who are victims of sexual violence) aged ten years and eleven years have been handled, as follows.

The first client, the client's complaint that is a child aged 10 (ten) years, has been a victim of sexual violence, for that it takes personality to see the extent to which events experienced affect the client in psychological terms. For the client's complaint, the procedure performed in carrying out the inspection is as follows. The first is a psychological examination of the client in the form of an interview about perceptions of self, family, the environment, trauma experienced, knowledge of the reproductive organs and views of the future. Then clinical observations are carried out, to see the behavior that appears during the assessment process, this serves to help as reinforcing data from other assessment processes carried out.

The next stage, a graphical test, is carried out in three parts, namely: a) draw a person test (DAP), which functions to see the client's perception of himself and others around him, b) the BAUM test/Tree test which functions to see aspects ego, emotional condition at that time, sensitivity to the environment, attitudes and perceptions in facing the future, c) House Tree Person test (HTP) that serves to see the client's perception of his family, and d) draw a family test is used to determine internal conflicts experienced by clients and fears, interactions and perceptions of family members. This test is carried out as an HTTP booster test.

Based on the examination carried out on the client (victim), the following results can be obtained. For yourself, the client is a child who has a difficult tendency to be obedient to authority figures (parents, teachers, and other older people), this is due to seek attention from both parents. Clients often feel that their parents are too busy so they don't take the time to be with them. Since his two younger siblings were born, he has to be an obedient and obedient child, so when a mother asks him for help with a gentle and understanding manner, the client will immediately obey.

The client's view of himself is very good; he can see the advantages possessed by himself. Even so, a family background that is not very good affects the development of inferiority tendencies in clients. This has an impact on the emergence of doubt in adaptation to his social environment, so he prefers to limit himself to playing with his friends. The ability of socialization is very good, but for the time being, he tends to limit it because of the problems experienced.

From the family side, the client has a good view of each family member, especially the mother. Even so, he did not have an emotional closeness to all family members. This is because family communication systems tend to be cold, and family time is rarely there. During that time, his parents were also often seen fighting, so sometimes he felt uncomfortable and blamed himself for it. The client's relationship with his older siblings is also not emotionally close. This is seen from the draw a family test, where the client refuses to color the entire picture of a family member. He explained that he only felt close to his younger brother who was still a baby because he would not scold or mock him when he told me something.

From the environmental side, the client is an individual who likes the process of social interaction, besides that he has a high enough dependence on others. But the condition of communication in the family that is not warm and negative views of the environment around him make it limit and cover themselves from the process of social interaction. Regarding the traumatic experience, the client has a positive view of the future; he tends to make the experience of sexual violence that he experienced as a lesson. He revealed that he must change into a better child, obey his parents and draw closer to religion for doing bad things. Throughout the assessment process to the client, it is indicated that he is less likely to experience certain trauma caused by the experience.

The second client, victims of sexual violence aged 11 (eleven) years old, so it takes a personality to see the extent to which the events experienced affect the client in psychological terms. Based on the psychological examination of the client in the form of clinical interviews, observations and graphic tests can be obtained as follows. 
Clinical interviews about perceptions of self, family environment, trauma experienced, knowledge of the reproductive organs as well as guidance on the future. Then clinical observations are carried out, to see the behavior that appears during the assessment process, this serves to help as reinforcing data from other assessment processes carried out. The next stage, a graphical test, is carried out in three parts, namely: a) draw a person test (DAP), which functions to see the client's perception of himself and others around him, b) the BAUM test / Tree test which functions to see aspects ego, emotional condition at that time, sensitivity to the environment, attitudes and perceptions in facing the future, c) House Tree Person test (HTP) which functions to see the client's perception of his family, d) WARTEGG test is used to measure the overall character of an individual based on cognitive, emotional, social and personality aspects. e) Dragon test is used to find out internal conflicts experienced by clients as well as fear, interaction, and perception of family members. This test is performed as a reinforcement of the HTP test results.

Based on the results of the examination, the client is a child who has a difficult tendency to comply with authority figures (parents, teachers, others who are older), this is because he considers himself to be worthless. He often feels neglected in the family, due to the busyness of both parents and siblings. The client feels that in this world he does not have anyone he trusts, this results in every time he has a problem he tends to solve it himself and hide it from the closest person.

Based on various tests given, it appears that the results of the client drawings are small and always in the left corner of the paper. This indicates that the client has a depressive phase, due to his poor self-concept. Poor selfconcept is likely due to a feeling of great inferiority so that in dealing with the problem the client tends to be less brave to act, repression (hiding the problem from others). Therefore, in living their lives the client is less friendly and lacks the fighting spirit.

In relationships with family, the client's view of the father figure is a figure that is far and not so close to him. During the assessment process, the client refuses to talk about his father. But in the HTP test and Dragon test, it appears that the client perceives the father as a person who does not undergo the function and role properly. Different things can be seen from the mother figure for the client, he sees that the mother is a strong and dominant person in his life, even though emotionally the client and mother are not close. This distant emotional relationship causes the client and mother to become very closed and away from each other when experiencing conflict.

Both tests regarding the family show that there is latent anger experienced by the client to his parents. Even so, he has chosen to ignore and harbor such anger so that it might have an impact on his parents' rejection. Assessment with the mother shows that while at home, the client is a child who always refuses when told. Besides, he tends to prefer playing alone compared to sitting together with all family members.

Concerning the environment, the client has a person who has good social skills and is very easy to adapt to the surrounding environment. Even so, poor self-concept and introvert personality and a great tendency to suppress the emotional expression that he felt made the client away from his social environment. Meanwhile, concerning traumatic experiences, based on the test equipment, it was concluded that there was aggressive suppression of the client. During the test work, the client uses the pencil roughly and strikes irregularly, even so, he does not leave marks on the back of the paper. Further assessment cannot be carried out because the client refuses to discuss it.

From the cognitive side, the client's cognitive abilities are indicated to have disturbances, during the process of working on the client's test must be given instructions many times and then start working. The possibility of the client-controlled by fantasy or shadow of past events they experienced. Besides the way the client reacts to problems or events in his life tends to be rushed and does not have a mature consideration. An assessment is needed to analyze this aspect.

Emotionally, the client tends to suppress aggression; this is the impact of feeling very helpless and low selfesteem. He also tends to act impulsively (without consideration) when one day he is no longer able to exercise selfcontrol. However, for this aspect further assessment is needed. Likewise, the client's knowledge about the body and reproductive organs, based on interviews conducted found that the client does not have enough understanding or knowledge about the body, as well as the body's reproductive system. Although at this time the client has experienced menstruation, he does not understand that this indicates a big change in him. He only assumed that menstruation was the thing that he should have experienced because now he was getting older. 
Based on the results of the analysis of the entire assessment process carried out to the client, it was concluded that the client had a self-concept and a bad view of himself. So he tends not to respect himself. Besides, the client is cognitively indicated to have a disorder, so there is a possibility that the occurrence of sexual violence experienced is also caused by the inability of the client to analyze the problem and consider the action taken. The client has an introverted personality tendency, so he prefers to be alone rather than having to interact with others. Individuals with introverted characters also tend to repress or suppress emotional responses or conflicts experienced. This has an impact on the depressive phase that may arise because he is unable to communicate the problem and share the emotions he feels with those around him.

Socially the client is an individual who is easily adaptable to others, even so, because of the feelings of inferiority and worthlessness that are so big owned makes the client a closed individual and tends to stay away from his social environment. The recommendations are given, psychological assistance that should be given to clients include four things, namely a. Advanced clinical psychology assessment, in the form of intelligence ability tests and other projective tests to see client perceptions about the sexual behavior they undergo. $b$. Trauma healing aims to get clients out of depression experienced. So the client can communicate well and eagerly live his life. c. Cognitive Behavior Therapy, done to prevent misconceptions about sexual behavior. The client will likely translate sexual behavior as something fun so this needs to be followed upon. d. Family therapy, done to improve the system in the family, a bad perception of the family is expected to change so that the client has a good and warm relationship with all family members.

From the interviews, the client can be seen clients often feel both parents are too busy so they don't spend time with him, family communication systems tend to be cold, and family time is rarely there. His parents are also often seen fighting, so sometimes he feels uncomfortable and blames himself for it. The client feels that in this world he does not have anyone he trusts, this results in every time he has a problem he tends to solve it himself and hide it from the closest person. There is a tendency for clients to only feel close to people they think will not scold or ridicule him when he tells something, in this case, the person is his baby sister.

When viewed from the environmental side, basically the two clients are individuals who like the process of social interaction, besides that he has a high enough dependence on others. However, due to the condition of communication in the family that is felt by the client is not warm and negative views of the environment around him make it limit and cover themselves from the process of social interaction. Likewise, because feelings of inferiority and worthlessness that are so great to have made clients become closed individuals and tend to stay away from their social environment.

Regarding the traumatic experience, the client has a positive view of the future; he tends to make the experience of sexual violence that he experienced as a lesson. He revealed that he must change into a better child, obey his parents and draw closer to religion for doing bad things. Throughout the assessment process to the client, it is indicated that he is not likely to experience the particular trauma caused by the experience.

Another problem that must be borne by the client and his family is the cost of psychological recovery of victims after the sexual violence they experienced. If we look at the costs that victims must incur during the process of psychological examination and recovery on the two clients of victims of sexual violence as described above, it can be concluded that these costs are not cheap. Therefore, in protecting children who are victims of sexual violence it is necessary to have such financial assistance through the process of submitting compensation, restitution, and compensation. This is what LPSK is fighting to protect child victims of sexual violence, even though the results are not as expected.

\section{Protection of Children Victims of sexual violence by KPAI}

Based on the results of interviews with the Deputy Chair of the KPAI in connection with the protection of children as victims of sexual violence (Pranawati, 2019), the following answers were obtained. SPPA tends to children as perpetrators. For child victims a little. Legal Aid Institutions do not accompany child victims, but rather children who become perpetrators because children are dealing with the law. The Hospital General does not have a free visa policy unless there is a recommendation from the National Commission that suggests a free visa. The Hospital Bhayangkara Cianjur, there is a special service. The problem is that the community's stigma towards victims is difficult to avoid. In schools, victims of sexual violence are excluded because of the good name of the school. 
Many victims were transferred to other schools; this greatly disrupted the learning process of children. Adjusting to the new environment is not easy for children. But if the child is not moved there is fear that the child's parents will be bullied by his friends.

Related to the obstacles faced by KPAI in protecting child victims of violence is the issue of child budget. The limited budget for children can only be done in the short term, even though children need prolonged treatment both for recovery and rehabilitation of psychologists. Children who are not handled properly can be crazy. Parental perspective cannot yet, parents should have the responsibility of caring for children sometimes often ignore the child because other matters that are considered more important. In practice, it is the region's business to assist child victims, but the regions have not yet implemented it. There must be a recovery process for the victim.

For example, KPAI in fighting for the rights of child victims after regional autonomy. Local government has no victim perspective. The Child Social Rehabilitation Agency needs Special Protection (BRS AMPK), specifically dealing with children who need special protection. But the regions state that they have a center, which has regions that are not very active. Regarding restitution rarely. Should have turned into state restitution. There is negligence in the context of state restitution. Trafficking cases have received restitution but they are very small. The ho spital, he said, was free of charge but in practice, it was not free.

\section{The decision of the Case of Sexual Violence in Children}

The study material used as the object of analysis in this Dissertation is a court decision at the first level, appeal level, and appeal level, for cases of sexual violence that occurred in DKI Jakarta and Bekasi, which occurred between 2006 and 2016, amounting to 11 decision. Of the 11 cases, 7 cases were criminal acts of sexual violence against children that occurred in DKI Jakarta, and 4 cases were criminal acts of sexual violence against children that occurred in Bekasi. While the perpetrators of sexual violence who make children as victims are generally adults.

The researchers' basic considerations took a period between 2006 and 2016 because in that period there were several changes to the rules regarding sexual violence with children as victims, both elements and criminal sanctions. The legislation governing sexual violence against children is as follows. Law Number 23 of 2002 concerning Child Protection took effect on October 22, 2002.

The rise of the crime of sexual violence against children in the community requires increased commitment from the Government, Regional Government, and the community as well as all stakeholders related to the implementation of Child Protection, making Law No. 23 of 2002 need to be changed. The amendment of Law Number 23 the Year 2002 to Law Number 35 the Year 2014 concerning Child Protection also emphasizes the need to impose criminal sanctions and fines for perpetrators of crimes against children, to provide a deterrent effect, and to encourage concrete steps to recover physically, psychologically. And socially the victim's child and/or the perpetrator's child. This needs to be done to anticipate child victims and/or children of perpetrators of crime in the future not to be the same perpetrators.

Looking at the cases of sexual violence against children that continue to occur, and have not fully caused a deterrent effect on the perpetrators, then to be able to cause a deterrent effect on the perpetrators, the rules governing sexual violence are amended by Law of the Republic of Indonesia Number 17 the Year 2016 concerning Establishment of Government Regulation instead of Law Number 1 Year 2016 Regarding the Second Amendment to Law Number 23 Year 2002 Regarding Child Protection Into Law, which came into force on the date of promulgation (Article 2), namely on November 9, 2016.

As for the consideration for the enactment of Law Number 17 of 2016 due to changes in the previous Act, namely Law Number 35 of 2014 has not significantly reduced the level of sexual violence against children, the State needs to take optimal and comprehensive steps by not only imposes criminal sanctions, also applies a form of prevention by providing actions in the form of chemical castration, electronic detection devices, and rehabilitation for perpetrators of sexual violence against children. To address the phenomenon of sexual violence against children, give a deterrent effect on perpetrators, and prevent sexual violence against children, the President has enacted Government Regulation instead of Law Number 1 of 2016 concerning Second Amendment to Law Number 23 of 2002 concerning Child Protection May 25, 2016.

The Government Regulation instead of Law Number 1 Year 2016 has received approval from the House of Representatives to then be ratified into Law on the Establishment of Government Regulation instead of Law Number 
1 of 2016 concerning Second Amendment to Law Number 23 of 2002 concerning Protection The child becomes a law based on the provisions of Article 22 paragraph (2) of the 1945 Constitution of the Republic of Indonesia.

To find out whether the amendment to the law provides legal protection for victims of sexual violence, the following is an analysis of court decisions regarding cases of sexual violence that make children victims, as follows:

a. Cases of Sexual Violence against Children in DKI Jakarta in a Court Decision

Research on the Court's Verdict on cases of sexual violence with child victims that occurred in the Special Capital Region of Jakarta (DKI Jakarta), as many as 7 (seven) cases, each of which the perpetrators (defendants) have been proven guilty and sentenced by the judge. The seven cases are as follows.

1) Decision Number 522/Pid.B / 2012 / PN.Jkt.Tim Jo. Decision Number 204 / PID / 2012 / PT.DKI Jo Decision Number 1878 K/ Pid.Sus / 2012.

2) Decision Number 08 / Pid.Sus.A / 2014 / PN. Jkt.Pst.

3) Decision Number 1168 / Pid.Sus / 2014 / PN. Jak Cell.

4) Decision Number 150 / Pid.Sus / 2015 / PN. Jak.Sel.

5) Decision Number 1397 / Pid.Sus / 2014 / PN. Jkt. Cell.

6) Decision Number 1089 / Pid.Sus / 2013 / PN. Jkt.Tim.

7) Decision Number 1288 / Pid.Sus / 2014 / PN. Jak.Sel.

\section{b. Cases of Sexual Violence against Children in Bekasi in a Court Decision.}

Subsequent research is on 4 (four) Court Decisions on cases of sexual violence against children that occurred in the Bekasi area, where each culprit (the defendant) has been proven guilty and the judge was sentenced. The four cases are as follows.

1. Decision Number 2144/Pid.B/2006/PN.Bks.

2. Decision Number 929/Pid.B/2013/PN.Bks.

3. Decision Number 221 / Pid.Sus / 2014 / PN.Bks.

4. Decision Number 546 / Pid.Sus / 2016 / PN.Bks.

\section{CONCLUSIONS AND RECOMMENDATIONS}

\section{Conclusion}

The protection of children who are victims of sexual violence is a very important need for children's growth and development going forward. Even though at first when the child was still unaware of what he was experiencing, namely violence against his body that contained sexual elements, but one day when the child realized what he was experiencing, it would be a disgrace to be endured for the rest of his life. Therefore early treatment is the most important way to do after sexual violence experienced by children. Protecting children who are victims of sexual violence will be very useful in treating physical wounds and psychological wounds of children to recover from illness and normal activities.

Based on the formulation of the problems in this dissertation, after conducting research based on the results of interviews with informants and analysis of cases of sexual violence against children who have been terminated by the court and occurred in the Jakarta and Bekasi, a conclusion can be obtained as follows:

1. Protection of children as victims of sexual violence must be a top priority and is something that cannot be delayed in its implementation. This is because the condition of children who are victims of sexual violence requires immediate treatment so that children can return to live their lives naturally; there is no prolonged trauma that will be fatal for the child's mental development going forward.

Ideally, protection for children as victims is carried out in every examination process until the punishment of the perpetrators. Therefore, in every examination process, from the police to the court, it is necessary to guarantee that the child is in a safe, comfortable and protected condition. It must be avoided questions, attitudes, gestures that can create pressure that causes the victim to feel scared and pressured so that they do not dare to reveal the events they experienced to find the perpetrators and process them legally. 
The punishment of the accused perpetrators of sexual violence against children is not only a serious crime, but it is also necessary to consider the need for compensation, restitution and assistance to the victim as an effort to treat and recover the physical and psychological conditions of the victim. As a consideration, the number of costs that must be borne by victims of sexual violence and their families includes the cost of post mortem report, psychological examination, and others. As an illustration, for examining the psychological condition of child victims of sexual violence handled by LPSK, not a few costs must be incurred for the psychological examination process of victims, even though these costs do not include post mortem costs or recovery of psychological conditions of victims to be released from the burden of suffering. Seeing so much the costs that must be incurred for the recovery of children who are victims of sexual violence, then in protecting children victims of sexual violence, regarding psychosocial assistance, LPSK is looking for the right formula to provide maximum protection for victims. Likewise, the rights of children who are victims of sexual violence as stipulated in the law as much as possible must be given, even if the child and his family are not aware of these rights. This will greatly benefit the victim to be able to return to have a hope of having a happy future.

2. Based on the results of research on cases of sexual violence against children that occurred in the Jakarta and Bekasi areas, none of the prosecutors in their demands requested that the judge who decided the sexual violence case impose a criminal offense in the form of giving restitution or compensation to the victim. This opinion was strengthened by the statement of the LPSK which stated that so far the children who had been victims of sexual violence had never been given restitution or compensation money from the perpetrators. One reason is that the perpetrators also come from poor families. Therefore, one of the efforts made by the LPSK is to collaborate with other agencies. The process in the criminal justice system so far has not thoroughly provided a place for child victims of sexual violence to get justice, because there is a tendency in cases that make children victims, law enforcers have not fully paid attention to the rights of children as victims as regulated in the law. However, because of the struggle of many parties who care about the increasing problems of children, then the need for protection of child victims has begun to receive attention.

3. Based on interviews with informants, to protect children who are victims of sexual violence, law enforcers such as the PPA Police Unit, Prosecutors, Judges, and Advocates must work together with institutions such as LPSK, KPAI, and LBH following their respective duties and authorities respectively. Problems in practice, because there is no appropriate system, the LPSK works on a case-by-case basis, so that the treatments given vary from case to case. But in broad outline, all the rights of child victims have been assisted, psychological and medical, but not specifically victims of sexual violence. Meanwhile, KPAI stated that it had never handled cases where victims received restitution or money to compensate victims of sexual violence from the perpetrators. The limited budget for children around the child can only be done for short-term handling, even though children need prolonged treatment both for recovery and psychological rehabilitation. Children who are not handled properly can be crazy. The parent's perspective has not been able to achieve the goal. In practice, it is the region's business to assist child victims, but the regions have not yet implemented it, but whatever the reason, there must be a process of recovery for victims. Arrangements in protecting children as victims of sexual violence to realize clear and complete formal justice have been regulated in several laws in force in Indonesia, namely in Law Number 23 of 2002 concerning Child Protection, Jo. Law Number 35 the Year 2014 Jo. Law Number 17 of 2016 concerning Child Protection; Law Number 13 Year 2006 Jo Law Number 34 Year 2014 concerning Protection of Witnesses and Victims, along with the implementing regulations, namely Government Regulation Number 44 of 2008 Jo Government Regulation Number 7 of 2018 concerning Provision of Compensation, Restitution and Assistance to Witnesses and Victims, Government Regulation Number 43 of 2017 concerning Implementation of Restitution for Children who are Victims of Criminal Acts. The law stipulates the rights of children as victims, criminal threats to perpetrators in the form of prisons and fines, and if those who commit sexual violence against children are parents, guardians, people who have family relationships, child caregivers, educators, educational staff, officers who deal with child protection, or are carried out by more than one person together, the recipient, the criminal is added $1 / 3$ (one third) of the criminal threat as referred to in paragraph (1). In the case of a criminal offense that causes more than 1 (one) person, resulting in serious injury, mental illness, infectious disease, disruption 
or loss of reproductive function, and/or death, the perpetrator is sentenced to death, life imprisonment, or a prison sentence of at least 10 (ten) years and a maximum of 20 (twenty) years. As a new form of crime against perpetrators of sexual violence against children, actions can be imposed in the form of chemical castration and chip installation.

4. Government Regulation No. 44 of 2008, as the implementing regulations for the provisions of Article 7 paragraph (3) and Article 34 paragraph (3) of Law Number 13 of 2006, has not provided compensation to victims of sexual violence but victims of gross human rights violations. Whereas the restitution charged to the offender is still constrained by the condition of the offender who is not a capable family. Furthermore, bearing in mind that this Government Regulation still encounters several obstacles and problems, Government Regulation No. 7 of 2018 was drafted regarding the Provision of Compensation, Restitution, and Assistance to Witnesses and Victims by the President on 1 March 2018. Additions to this Government Regulation include a detailed description of the restitution component (compensation from perpetrators for victims), to the expansion of victims of criminal acts who are entitled to assistance.

The breakdown of the component of calculating restitution is considered important because it can be the legal basis for the amount of restitution submitted. Previously, there was a debate about the basic value of the amount of restitution calculated by LPSK, because it was considered that there was no clear basis. As a result, it is not uncommon for the amount to be reduced when sentenced, or even rejected by the judge. The existence of this PP is expected to further strengthen witness protection and fulfillment of victims' rights. Related to aid, in Government Regulation No.7 of 2018, in addition to victims of acts of terrorism, human trafficking, torture, and serious torture, assistance is also given to victims of sexual violence. This is of course very important considering victims of sexual violence are in dire need of assistance in terms of medical, psychological, and social psycho services. The expansion of the types of criminal acts for which victims can be assisted is very positive given the trauma they experienced must, of course, be recovered including through relief efforts.

5. In practice, although there are rules regarding compensation, restitution, and assistance to victims as above, the regulation has not been fully implemented so that it cannot yet be said to protect victims (children) of sexual violence. Likewise, the unclear rules regarding the implementation of castration crime, which is an understanding of castration crime itself, still arise (pros and cons) between law enforcement officials, legal experts, as well as executors and the public. Therefore, this in-depth study of castration crime from various disciplines must be carried out immediately so that it will be useful in protecting children as victims of sexual violence without creating new problems that are detrimental to the victim.

\section{Recommendations}

Based on the above conclusions which are answers to the formulation of the problem as stated in the first chapter of this paper, then after an in-depth study of cases of sexual violence that have been decided by the court and have permanent legal force, in the end, the author submits some recommendations which would be useful in protect children as victims of sexual violence as follows.

1. In every examination process to prove the wrongdoing of the perpetrators, whether requested or not, the victim (child) must be given maximum assistance. To realize fair and beneficial law enforcement and provide protection to victims (children), it is necessary for law enforcers to be more sensitive in understanding the problem of children as victims, how victims' rights must be respected and fulfilled. Likewise, in the punishment of perpetrators of sexual violence with children as victims, in addition to imprisonment and fines imposed on the perpetrators, crimes must also be included in the form of compensation, restitution, and assistance to victims.

2. To create a criminal justice system to provide a place for victims (children) of sexual violence to get justice, it will be very meaningful for victims of law enforcement agencies work together with other agencies such as LPSK, KPAI, LBH children to immediately implement the granting of children's rights as victims especially those relating to the provision of compensation, restitution, and assistance as provided for in the law.

3. To be able to create an ideal legal rule, which protects children (victims) of sexual violence, as soon as possible clear rules of implementation are made and do not cause multiple interpretations that can harm the 
victim. Besides, to facilitate law enforcement implementing appropriate measures in determining the wrongdoers of sexual violence, it is necessary to stipulate in the law a criterion on the category of sexual violence, namely:

4. Severe sexual violence, i.e. "every act of violence or threat of violence carried out to commit promiscuity or fornication resulting in victims of contracting a dangerous disease, or seriously injured or dying".

5. Moderate sexual violence, i.e. "every act of violence or threat of violence accompanied by sexual lust done by kissing the lips, squeezing, or other obscene acts, which does not result in victims of injury, illness or health problems".

6. Mild sexual violence is "any act of violence or threat carried out by touching or touching that does not result in injuries, illness or health problems".

\section{References}

A.Z. Abidin Farid dan A. Hamzah. Bentuk-bentuk Khusus Perwujudan Delik (Percobaan, Penyertaan, dan Gabungan Delik) dan Hukum Penitensier. Jakarta : RajaGrafindo Persada, 2006.

Abdul Wahid, dan Irfan Muhammad. Perlindungan Korban Kekerasan seksual. Advokasi atas Hak Asasi Perempuan. Cetakan kedua. Jakarta : PT Refika Aditama, 2011.

Adami, Chazawi, Tindak Pidana Pornografi. Penyerangan terhadap Kepentingan Hukum Mengenai Tegaknya Tatanan Kehidupan akhlak dan Moral Kesusilaan Yang Menjunjung Tinggi Nilai-Nilai Ketuhanan Yang Maha Esa Dan Kemanusiaan Yang Adil Dan Beradab. Surabaya : PMS, 2009.

Agus, Takariawan, Perlindungan Saksi Dan Korban. Cetakan ke-1. Bandung : Pustaka Reka Cipta, 2016.

Andika Wijaya, Wida Peace Ananta, Darurat Kejahatan Seksual. Cetakan pertama. Jakarta : Sinar Grafika, 2016.

Arif, Gosita, Masalah Perlindungan Anak. Jakarta : Akademika Pressindo, 1989.

Bambang, Waluyo, Pidana dan Pemidanaan. Jakarta : Sinar Grafika, Cetakan kedua, 2004.

Bambang, Waluyo, Viktimologi, Perlindungan Korban dan Saksi. Jakarta Sinar Grafika, 2016.

Barda, Nawawi Arief. Bunga Rampai Kebijakan Hukum Pidana,Bandung : Citra Aditya Bakti, 1996.

Barda, Nawawi Arief.,.Perbandingan Hukum Pidana, Jakarta : PT Raja GrafindoPersada, 2003.

Belli Jenawi, Kajian Kendala Dalam Perlindungan Hukum Oleh Aparat Penegak Hukum Terhadap Anak Korban Pelecehan Seksual (Ditinjau dari UU No. 35 Tahun 2014), Lex Crimen, Vol.VI/No. 8/Okt/2017.

Boy, Nurdin, Filsafat Hukum, Tokoh-Tokoh Penting Filsafat : Sejarah dan Intisari Pemikiran. Jakarta : Litera Antar Nusa, Edisi pertama, 2014.

C. Maya Indah, Perlindungan Korban, Suatu Perspektif Viktimologi dan Kriminologi, Jakarta : Kencana Prenadamedia Group, 2014.

Chairul, Huda, Dari Tiada Pidana Tanpa Kesalahan Menuju Kepada Tiada Pertanggungjawaban Pidana Tanpa Kesalahan., Tinjauan Kritis Terhadap Teori Pemisahan Tindak Pidana dan Pertanggungjawaban Pidana, edisi pertama, Jakarta : Prenadamedia Group, cetakan kelima, 2015.

Deklarasi Prinsip-Prinsip Dasar Keadilan Bagi Korban Kejahatan dan Penyalahgunaan Kekuasaan, yang dikeluarkan pada tahun 1985 sebagai Resolusi PBB Nomor 40/34 Tanggal 2 Nopember 1985.

Dian Puji, N Simatupang, Paradoks Rasionalitas Perluasan Ruang Lingkup Keuangan Negara dan Implikasinya terhadap Kinerja Keuangan Pemerintah. Jakarta : Bagian Penerbit FHUI, 2011.

Direktur Jenderal Bina Kesehatan Masyarakat Departemen Kesehatan Republik Indonesia. (Unicef, Buku Pedoman Deteksi Dini, Pelaporan Dan Rujukan Kasus Kekerasan dan Penelantaran Anak Bagi Tenaga Kesehatan).

Eddy, O.S, Hiariej. Teori \& Hukum Pembuktian, Jakarta : Penerbit Erlangga, 2012. 
International Journal of Humanities and Applied Social Science (IJHASS)

E-ISSN: 2471-7576

February 2020, Vol: 5, Issue: 2

E-mail: editor@ijhassnet.com

http://ijhassnet.com/

DOI: 10.33642/ijhass.v5n2p1

CCenter for Promoting Education and Research (CPER) USA, www.cpernet.org

Erasmus, Napitupulu, "Jurnal Perlindungan", edisi 4 volume 1 Tahun 2014. LPSK : Peran dan Pengalaman Penegakakn Hukum terkait Perlindungan Saksi dan Korban untuk Beberapa Kasus (Hak Asasi Manusia, KDRT, TPPO dan Korupsi).

Fakultas Hukum, Petunjuk Penulisan Disertasi Program Doktor Ilmu Hukum Fakultas Hukum Universitas Krisnadwipayana, 2014.

Farah Noersativa,Perkara Kekerasan Anak di Kota Bekasi, REPUBLIKA.CO.ID, BEKASI, Senin 08 Januari 2018, diakses 10 September 2018.

H.A.K. Moch, Anwar, KUHP Buku II. Bandung : Alumni, 1981.

H.R. Abdussalam, Kriminologi. Jakarta : Restu Agung, cetakan ketiga, 2007.

Herkutanto, Kekerasan Terhadap Perempuan dan Sistem Hukum Pidana Pendekatan dari Sudut Pandang Kedokteran. Bandung : Alumni, 2000.

I Dewa, Gede Atmadja, Filsafat Hukum, Dimensi Tematis dan Historis, Malang : Setara Press, 2013.

I.S. Susanto, Kriminologi. Yogyakarta, Genta Publishing, 2011.

Indiana Malia. KPAI : Korban Kekerasan Seksual Anak Didominasi Laki-Laki, Jakarta, IDN Times, 28 Desember 2018.

Indonesia, Peraturan Pemerintah Pengganti Undang-Undang (PERPPU) Nomor 1 Tahun 2016 Tentang Perubahan Kedua Undang-Undang Nomor 23 Tahun 2002 TentangPerlindunganAnak. (Lembaran Negara Republik Indonesia Tahun 2016 Nomor 99, Ta mbahanLembaran Negara Republik Indonesia Nomor 5882).

Indonesia, Undang-Undang Nomor 23 Tahun 2002 Tentang Perlindungan Anak, Lembaran Negara Republik Indonesia Tahun 2002 Nomor 109, Tambahan Lembaran Negara Republik Indonesia Nomor 4235.

Indonesia, Undang-Undang Nomor 8 Tahun 1981 Tentang Kitab Undang-Undang Hukum Acara Pidana (KUHAP), Lembaran Negara Republik Indonesia Tahun 1981 Nomor 76, Tambahan Lembaran Negara Republik Indonesia Nomor 3209.

Indonesia, Undang-Undang Nomor 11 Tahun 2012 Tentang SistemPeradilan Pidana Anak. Lembaran Negara Republik Indonesia Tahun 2012 Nomor 153, Tambahan Lembaran Negara Republik Indonesia Nomor 5332.

Indonesia, Undang-Undang Nomor 13 Tahun 2006 Tentang Perlindungan Saksi dan Korban, Lembaran Negara Republik Indonesia Tahun 2006 Nomor 64, Tambahan Lembaran Negara Republik Indonesia Nomor 4635.

Indonesia, Undang-Undang Nomor 17 Tahun 2016 Tentang Penetapan Peraturan Pemerintah Pengganti UndangUndang Nomor 1 Tahun 2016 Tentang Perubahan Kedua Atas Undang-Undang Nomor 23 Tahun 2002 Tentang Perlindungan Anak Menjadi undang-undang.

Indonesia, Undang-Undang Nomor 21 Tahun 2007 Tentang Pemberantasan Tindak Pidana Perdagangan Orang. Lembaran Negara Republik Indonesia Tahun 2007 Nomor 58, Tambahan Lembaran Negara Republik Indonesia Nomor 4720.

Indonesia, Undang-Undang Nomor 31 Tahun 2014 Tentang Perubahan Atas Undang-Undang Nomor 13 Tahun 2006 Tentang Perlindungan Saksi dan Korban, Lembaran Negara Republik Indonesia Tahun 2014 Nomor 293, Tambahan Lembaran Negara Republik Indonesia Nomor 5602.

Indonesia, Undang-Undang Nomor 35 Tahun 2014 Tentang Perubahan Atas Undang-Undang Nomor 23 Tahun 2002

Tentang Perlindungan Anak, Lembaran Negara Republik Indonesia Tahun 2014 Nomor 297, Tambahan Lembaran Negara Republik Indonesia Nomor 5606.

Indonesia, Undang-Undang Nomor 39 Tahun 1999 Tentang Hak Asasi Manusia. Lembaran Negara Republik Indonesia Tahun1999 Nomor 165, Tambahan Lembaran Negara Republik Indonesia Nomor 3886.

Indonesia, Undang-Undang Nomor 4 Tahun 1979 Tentang Kesejahteraan Anak. Lembaran Negara Republik Indonesia Tahun1979 Nomor 32, Tambahan Lembaran Negara Republik Indonesia Nomor 5332.

Indonesia, Undang-UndangNomor 1 Tahun 1946 Tentang Kitab Undang-Undang Hukum Pidana.

Indonesia,Undang-UndangNomor 23 Tahun 2004 Tentang Penghapusan Kekerasan Dalam Rumah Tangga, Lembaran Negara Republik Indonesia, Tahun 2004 Nomor 95, Tambahan Lembaran Negara Republik Indonesia Nomor 4419. 
Irma, Setyowati, Soemitro, Aspek Hukum Perlindungan Anak, Jakarta : Bumi Aksara, 1990.

J.M. Van Bemmelen, Hukum Pidana 2 (terjemahan Hasnan). Bandung : Bina Cipta, 1986.

J.M. Van Bemmelen, Van, Bemmelen, Hukum Pidana I . Bandung : Bina Cipta, 1987.

Jan, Remmelink, Hukum Pidana, Komentar atas Pasal-Pasal Terpenting dari KitabUndang-Undang Hukum Pidana

Belanda dan Padanannya dalam Kitab Undang-Undang Hukum Pidana Indonesia, Jakarta : PT Gramedia Pustaka Utama, 2003.

Karen, Lebacqz, Teori-Teori Keadilan, Six Theories of Justice, Bandung: Nusa Media, 1986.

Kementerian Kominfo, Indonesia Darurat Kekerasan Seksual pada Anak.

Koesparmono, Irsan, Perlindungan Anak Dan Wanita. Jakarta : Universitas Bhayangkara, 2008.

Komisi Perlindungan Anak Indonesia Bidang Data Informasi dan Pengaduan.

Komnas Perempuan, Modul Pelatihan, Menumbuhkan Sensitivitas Hak Asasi Manusia dan Gender Bagi Aparat

Penegak Hukum dalam Penanganan Kasus-Kasus Kekerasan terhadap Perempuan di Lingkungan Peradilan Umum, 2011.

Konvensi Internasional Hak-Hak Anak. Jakarta : Yayasan Obor Indonesia,1998.

M, Abdullah Surjaya, Bekasi Darurat Kejahatan Seksual Anak, Koran Sindo, Edisi 01-04-2017, diakses 10

September 2018.

M. Arief Amrullah. Politik Hukum Pidana Dalam Rangka Perlindungan Korban Kejahatan Ekonomi di Bidang

Perbankan. Malang : Bayu Media Publishing, 2003.

M. Azis, Syamsuddin. Perlindungan Saksi dan Korban, Menuju Proses Peradilan yang Adil. Jakarta : Indonesia, cetakan pertama, 2006.

M.L. Hc Hulsman, Sistem Peradilan Pidana, Jakarta, CV Rajawali, cetakan pertama, 1984.

Made, Darma Weda, Teori Kriminologi, Yogyakarta :Genta Publishing, cetakan pertama, 2017.

Maharani, Siti Shopia, Aksesibilitas Korban Kejahatan Dalam Sistem Peradilan Pidana, Jurnal Perlindungan, Lembaga Perlindungan saksi dan Korban Republik Indonesia, edisi 4 Vol.1 Tahun 2014

Mahrus, Ali, Dasar-Dasar Hukum Pidana. Jakarta : Sinar Grafika, 2011.

Maidin, Gultom,. Perlindungan Hukum Terhadap Anak. Dalam Sistem Peradilan Pidana Anak Di Indonesia.

Cetakan Keempat Revisi. Bandung : PT. Refika Aditama, 2014

Mardjono, Reksodiputro, HakAsasiManusiaDalamSistemPeradilanPidana. Jakarta : Pusat Pelayanan Keadilan Dan

Pengabdian Hukum, Lembaga Kriminologi UI, 1999.

Matius Alfons, LPSK Kasus Kekerasan seksual pada Anak Meningkat Tiap Tahun, detikNews. 24 Juli 2019.

Moeljatno, Asas-Asas Hukum Pidana, cetakan kedelapan, Edisi Revisi. Jakarta : Rineka Cipta, 2008.

Mudzakkir, Kedudukan Korban Tindak Pidana Dalam Sistem Peradilan Pidana Indonesia Berdasarkan KUHP dan RUU KUHP, “Jurnal Ilmu Hukum”, Volume 14 No.1 Maret 2011.

Muhamad, Erwin, Filsafat Hukum, Refleksi Kritis terhadap Hukum. Jakarta : PT. RajaGrafindo Persada, cetakan ke3, 2013.

Muhammad, Rusli, Sistem Peradilan Pidana Indonesia . Yogyakarta : UII Press, 2011.

Muladi, dan Barda Nawawi, Teori-Teori dan Kebijakan Pidana. Bandung : Alumni, 1984.

Muladi, Hak Asasi Manusia, Politik dan Sistem Peradilan Pidana, Semarang : UNDIP, 1997.

Muladi, Kapita Selekta Sistem Peradilan Pidana, Semarang : UNDIP, 1995.

Munir, Fuady, Teori Hukum Pembuktian Pidana dan Perdata. Bandung : PT Citra Aditya Bakti, 2012.

Nur Iman Subono, Kekuasaan Negara, Seksualitas dan Perubahan Kebijakan di Amerika Latin, “Jurnal Perempuan” No. 41 untuk pencerahan dan kesetaraan.

Peraturan Kepala Kepolisian Nomor 10 Tahun 2007 tentang Organisasi Tata Kerja Unit Pelayanan Perempuan dan Anak (PPA) di Lingkungan Kepolisian Negara Republik Indonesia.

Peraturan Menteri Negara Pemberdayaan Perempuan Dan Perlindungan Anak Republik Indonesia Nomor 02 Tahun 2011 Tentang Pedoman Penanganan Anak Korban Kekerasan.

Peraturan Pemerintah Nomor 44 Tahun 2008 Tentang Pemberian Kompensasi, Restitusi dan Bantuan Kepada Saksi dan Korban. 
Peraturan Pemerintah Nomor 7 Tahun 2018 Tentang Pemberian Kompensasi, Restitusi Dan Bantuan Kepada Saksi dan Korban.

Peraturan Pemerintah Republik Indonesia Nomor 17 Tahun 2017 tentang Pelaksanaan Restitusi Bagi anak Yang Menjadi Korban Tindak Pidana,

Perlu adanya Koreksi terhadap Hukuman", Forum Keadilan, No. 35. 03 Januari 2010.

Putusan Mahkamah Agung Nomor 1878 K/Pid.Sus/2012.

Putusan Pengadilan Negeri Jakarta Pusat Nomor 08/Pid.Sus.A/2014/PN. Jkt.Pst.

Putusan Pengadilan Negeri Jakarta Selatan Nomor 150/Pid.Sus/2015/PN. Jak.Sel.

Putusan Pengadilan Negeri Jakarta Selatan Nomor 1168/Pid.Sus/2014/PN. Jak Sel.

Putusan Pengadilan Negeri Jakarta Selatan Nomor 1288/Pid.Sus/2014/PN. Jak.Sel.

Putusan Pengadilan Negeri Jakarta Selatan Nomor 1397/Pid.Sus/2014/PN. Jkt. Sel.

Putusan Pengadilan Negeri Jakarta Timur Nomor 1089/Pid.Sus/2013/PN. Jkt.Tim.

Putusan Pengadilan Negeri Jakarta Timur Nomor 405/Pid.Sus/2018/PN.Jkt. Tim.

Putusan Pengadilan Negeri Bekasi Nomor 2144/Pid.B/2006/PN.Bks.

Putusan Pengadilan Negeri Bekasi Nomor 221/Pid.Sus/2014/PN.Bks.

Putusan Pengadilan Negeri Bekasi Nomor 546/Pid.Sus/2016/PN.Bks.

Putusan Pengadilan Negeri Bekasi Nomor 929/Pid.B/2013/PN.Bks.

Putusan Pengadilan Negeri Jakarta Timur Nomor 1089/Pid.Sus/2013/PN.Jkt. Tim,

Putusan Pengadilan Negeri Jakarta Timur Nomor 522/Pid.B/2012/PN.Jkt.Tim.

Putusan Pengadilan Tinggi Daerah Khusus Ibu kota Jakarta Nomor 204/PID/2012/PT.DKI.

R. Sugandhi, KUHP dan Penjelasannya. Surabaya : Usaha Nasional, 1981.

Rancangan Undang-Undang Tentang Penghapusan Kekerasan Seksual Didasarkan Pada Progres Kemajuan sampai dengan 1 September 2015.

Rena, Yulia, Viktimologi, Perlindungan Hukum Terhadap Korban Kejahatan. Cetakan pertama. Yogyakarta : Graha Ilmu, 2010.

Roeslan Saleh, Stelsel Pidana Indonesia. Jakarta : Aksara Baru.

Roeslan Saleh, Perbuatan Pidana dan Pertanggungjawaban Pidana. Dua Pengertian Dasar Dalam Hukum Pidana. Jakarta : Aksara Baru, 1983.

Romli, Atmasamita, Sistem Peradilan Pidana, Perspektif Eksistensialisme dan Abolisionisme. Bandung : Bina Cipta, 1996.

Siska, Lis Sulistiani, Kejahatan dan Penyimpangan Seksual dalam Perspektif Hukum Islam dan Hukum Positif Indonesia, Bandung : Nuansa Aulia, Cetakan I, 2016.

Siswanto, Sunarso, Viktimologi dalam Sistem Peradilan Pidana. Jakarta :SinarGrafika, cetakan pertama, 2012.

Soeharto, Perlindungan Hak Tersangka, Terdakwa dan Korban, Tindak Pidana Terorisme Dalam Sistem Peradilan Pidana, Bandung : Refika aditama, 2007

Soenarto, Soerodibroto, KUHP dan KUHAP Dilengkapi Yurisprudensi Mahkamah Agung Dan Hoge Raad, edisi kelima, Jakarta : RajaGrafindo Persada, 2003.

Soerjono Soekanto, Herkutanto dan Budi Sampurno, Visum Et Repertum Visum Et Repertum, Teknik Penyusunan Dan Pemerian. Jakarta : IND-HILL-C0, 1987.

Stephen Schafer, Sistem Peradilan Pidana Kontemporer, Jakarta : Prenada Media Group, 2010.

Stephen Schafer, (dalam Made Darma Weda, Teori Kriminologi, Yogyakarta ; Genta Publishing, cetakan pertama, 2017, hlm., 93.

Sudradjat, M Bassar, Tindak-Tindak Pidana Tertentu di Dalam Kitab Undang-undang Hukum Pidana, Bandung : Remadja Karya, 1986.

Syahrial Martanto, Wiryawan, Perlindungan Hak-Hak Korban Kejahatan, Perubahan Undang-Undang Dan Tantangannya Dalam Pembaharuan Hukum Pidana Nasional. "Jurnal Perlindungan" Volume 5 Nomor 1, Desember 2015.

Teguh, Prasetyo, Filsafat, TeoridanIlmuHukum, Pemikiran Menuju Masyarakat yang Berkeadilan dan Bermanfaat. Jakarta : PT RajaGrafindo Persada, 2012. 
International Journal of Humanities and Applied Social Science (IJHASS)

E-ISSN: 2471-7576

February 2020, Vol: 5, Issue: 2

E-mail: editor@ijhassnet.com

http://ijhassnet.com/

DOI: 10.33642/ijhass.v5n2p1

(C)enter for Promoting Education and Research (CPER) USA, www.cpernet.org

Teguh, Prasetyo,. Kriminalisasi Dalam Hukum Pidana. Bandung : Nusa Media, cetakan 1, 2010.

Temmangnganro Machmud, Perlindungan Hukum Terhadap Anak Korban Kekerasan Seksual Dalam Sistem

Peradilan Pidana Terpadu Di Wilayah Kota Pontianak. Jurnal Nestor Magister Hukum, Universitas

Tanjungpura, 2012. 